\title{
An evaluation of three methods for measuring black carbon in Alert, Canada
}

\author{
Sangeeta Sharma ${ }^{1}$, W. Richard Leaitch ${ }^{1}$, Lin Huang ${ }^{1}$, Daniel Veber ${ }^{1}$, Felicia Kolonjari ${ }^{1}$, Wendy Zhang $^{1}$, \\ Sarah J. Hanna ${ }^{2}$, Allan K. Bertram ${ }^{2}$, and John A. Ogren ${ }^{3,4}$ \\ ${ }^{1}$ Climate Chemistry Measurements and Research, Climate Research Division, Atmospheric Science and Technology \\ Directorate, Environment and Climate Change Canada, 4905 Dufferin Street, Toronto, ON, M3H 5T4, Canada \\ ${ }^{2}$ Department of Chemistry, University of British Columbia, Vancouver, BC, Canada \\ ${ }^{3}$ Cooperative Institute for Research in Environmental Sciences, University of Colorado, Boulder, CO 80309 USA \\ ${ }^{4}$ NOAA/ESRL Global Monitoring Division, 325 Broadway R/GMD, Boulder, CO 80305 USA
}

Correspondence: Sangeeta Sharma (sangeeta.sharma@canada.ca)

Received: 12 April 2017 - Discussion started: 19 May 2017

Revised: 27 October 2017 - Accepted: 3 November 2017 - Published: 22 December 2017

\begin{abstract}
Absorption of sunlight by black carbon (BC) warms the atmosphere, which may be important for Arctic climate. The measurement of $\mathrm{BC}$ is complicated by the lack of a simple definition of $\mathrm{BC}$ and the absence of techniques that are uniquely sensitive to BC (e.g., Petzold et al., 2013). At the Global Atmosphere Watch baseline observatory in Alert, Nunavut $\left(82.5^{\circ} \mathrm{N}\right), \mathrm{BC}$ mass is estimated in three ways, none of which fully represent $\mathrm{BC}$ : conversion of light absorption measured with an Aethalometer to give equivalent black carbon (EBC), thermal desorption of elemental carbon (EC) from weekly integrated filter samples to give $\mathrm{EC}$, and measurement of incandescence from the refractory black carbon (rBC) component of individual particles using a single particle soot photometer (SP2). Based on measurements between March 2011 and December 2013, EBC and $\mathrm{EC}$ are 2.7 and 3.1 times higher than $\mathrm{rBC}$, respectively. The $\mathrm{EBC}$ and $\mathrm{EC}$ measurements are influenced by factors other than just $\mathrm{BC}$, and higher estimates of $\mathrm{BC}$ are expected from these techniques. Some bias in the rBC measurement may result from calibration uncertainties that are difficult to estimate here. Considering a number of factors, our best estimate of $\mathrm{BC}$ mass in Alert, which may be useful for evaluation of chemical transport models, is an average of the $\mathrm{rBC}$ and $\mathrm{EC}$ measurements with a range bounded by the rBC and EC combined with the respective measurement uncertainties. Winter, spring-, summer-, and fall-averaged ( \pm atmospheric variability) estimates of $\mathrm{BC}$ mass in Alert for this study period are $49 \pm 28,30 \pm 26,22 \pm 13$, and $29 \pm 9 \mathrm{ng} \mathrm{m}^{-3}$, respec-
\end{abstract}

tively. Average coating thicknesses estimated from the SP2 are 25 to $40 \%$ of the $160-180 \mathrm{~nm}$ diameter rBC core sizes. For particles of approximately $200-400 \mathrm{~nm}$ optical diameter, the fraction containing $\mathrm{rBC}$ cores is estimated to be between 10 and $16 \%$, but the possibility of smaller undetectable rBC cores in some of the particles cannot be excluded. Mass absorption coefficients (MACs) \pm uncertainty at $550 \mathrm{~nm}$ wavelength, calculated from light absorption measurements divided by the best estimates of the $\mathrm{BC}$ mass concentrations, are $8.0 \pm 4.0,8.0 \pm 4.0,5.0 \pm 2.5$ and $9.0 \pm 4.5 \mathrm{~m}^{2} \mathrm{~g}^{-1}$, for winter, spring, summer, and fall, respectively. Adjusted to better estimate absorption by BC only, the winter and spring values of MACs are $7.6 \pm 3.8$ and $7.7 \pm 3.8 \mathrm{~m}^{2} \mathrm{~g}^{-1}$. There is evidence that the MAC values increase with coating thickness.

\section{Introduction}

Black carbon (BC) is a component of the atmospheric aerosol that strongly absorbs shortwave radiation. A comprehensive review suggests the impact of $\mathrm{BC}$ on direct radiative forcing of the atmosphere is $0.71 \mathrm{~W} \mathrm{~m}^{-2}$, with an uncertainty range of +0.08 to $+1.27 \mathrm{~W} \mathrm{~m}^{-2}$ (Bond et al., 2013). BC is a shortlived climate forcer due to its relatively short atmospheric lifetime of a few days to a few weeks. It has been suggested that mitigation of $\mathrm{BC}$ emissions may reduce warming of the Arctic atmosphere in the short term (UNEP/WMO, 2011; 
AMAP, 2015; Sand et al., 2016). BC results from incomplete combustion of carbonaceous fuels, and the definition of $\mathrm{BC}$ is complex (Andreae and Gelencsér, 2006; Bond et al., 2013; Petzold et al., 2013). Most of the BC in Arctic aerosol particles is transported to the Arctic from lower-latitude sources during winter and spring (e.g., Barrie, 1986; Sharma et al., 2004; Stone et al., 2015). The Arctic atmosphere is relatively stable, resulting in pollution transport into the Arctic often occurring in layers. $\mathrm{BC}$ in particles will warm the atmospheric layer in which they reside, while the reflective components of the particles (e.g., sulfate, non-absorbing components of organics) cool the atmosphere and surface below the layer. The degree of heating of the layer and cooling of the surface below depends in part on the albedo of the surface below: surfaces with relatively high albedos (snow, ice, and clouds) are cooled less and could enhance warming by the absorbing layer. Aerosol particles containing BC in layers well above the surface will tend to increase the stability of the Arctic atmosphere (e.g., Brock et al., 2011), whereas those transported near the surface may warm the air over highly reflective surfaces and even the less reflective surfaces that are found in the Arctic during summer (e.g., Iziomon et al., 2006). Deposition of BC can lower the albedo of snow- and ice-covered areas of the Arctic, making another contribution to Arctic warming (Clarke and Noone, 1985; McConnell et al., 2007; Hegg et al., 2009; Keegan et al., 2014; Dumont et al., 2014). Outside of the Arctic, BC can alter latitudinal temperature gradients, which may be more important for Arctic warming than absorption within the Arctic (Sand et al., 2013).

Measurements of $\mathrm{BC}$ in the Arctic are relatively scarce; our long-term knowledge of $\mathrm{BC}$ has been based on light absorption measurements of particles that are converted to EBC mass concentrations using a mass absorption coefficient (MAC) (e.g., Sharma et al., 2004, 2006; Eleftheriadis et al., 2009; Massling et al., 2015). BC is insoluble in water and organic solvents, and it is refractory to over $3600^{\circ} \mathrm{C}$ (Schwarz et al., 2006; Petzold et al., 2013). Freshly emitted $\mathrm{BC}$ particles often exhibit complex morphologies that change as $\mathrm{BC}$ becomes internally mixed with other aerosol components; this aging process can alter the absorption properties (e.g., Petzold et al., 2013). Particle absorption is also affected by dust and by brown carbon $(\mathrm{BrC})$, the latter of which arises from anthropogenic sources (e.g., Petzold et al., 2009, 2011) and biomass burning (e.g., Hoffer et al., 2006; Andreae and Gelencsér, 2006). In addition to the presence of other absorbing components of the atmospheric aerosol, light absorption measurements used to estimate $\mathrm{BC}$ are complicated by absorption enhancement by the filtering media and the uncertainty in the MAC value. Thus, more direct techniques to measure $\mathrm{BC}$ are necessary.

Estimates of $\mathrm{BC}$ mass concentrations are made at the Dr. Neil Trivett Global Atmospheric Watch (GAW) Observatory in Alert, Nunavut, Canada $\left(82.5^{\circ} \mathrm{N}, 62.5^{\circ} \mathrm{W}\right.$; 185 m a.m.s.l.), using three approaches. Since May 1989, light absorption by particles has been measured with an Aethalometer (Hopper et al., 1994; Sharma et al., 2004, 2006). The light attenuation is converted to $\mathrm{BC}$ using a MAC value, which is an indirect method for estimating $\mathrm{BC}$ referred to as equivalent black carbon (EBC) (Petzold et al., 2013). Weekly averaged collections of particles on quartz filters were initiated in 2005. The filters are subsequently analyzed for elemental carbon (EC) and organic carbon (OC) using an in-house thermal technique known as EnCan-total-900 (Huang et al., 2006; Chan et al., 2010). In 2011, a Droplet Measurements Technologies, Inc. single particle soot photometer (SP2) (Stephens et al., 2003; Schwarz et al., 2006) was installed in Alert enabling real-time measurements of refractory black carbon (rBC) based on the incandescence of individual particles heated to $3600^{\circ} \mathrm{C}$. Also, light absorption measurements at three wavelengths were made with a particle soot absorption photometer (PSAP; Radiance Research Inc.). An instrument based on acoustic detection was also deployed in Alert to estimate $\mathrm{BC}$, but the necessary sensitivity in the relatively low-concentration environment could not be achieved and it is not included in the discussion here.

The objective of this paper is to improve the characterization of $\mathrm{BC}$ and MAC values in the high Arctic. Presented here are comparisons of $\mathrm{EBC}, \mathrm{EC}$, and $\mathrm{rBC}$ observations made at the Alert observatory for the period from March 2011 to December 2013. In addition, number and mass size distributions, as well as coating thicknesses of the rBC particles, are discussed. These results are the first reported measurements of rBC over an extended period at any high Arctic location as well as the first seasonal comparison of rBC to EBC and EC. In Sect. 2, the measurement techniques and analysis methods are discussed. Section 3 presents time series and seasonal variations of masses of $\mathrm{rBC}, \mathrm{EBC}$, and $\mathrm{EC}$ as well as rBC number size distributions and coating thicknesses. The discussion in Sect. 4 addresses some questions raised by the results of this work, such as why the responses of the instruments to aerosol black carbon are different in Alert; how the MAC value varies seasonally; and how these results compare with other related studies. Section 5 summarizes the findings and identifies the conclusions.

\section{Methods}

\subsection{Sampling}

The Alert Observatory is a global station within the World Meteorological Organization GAW program (Fig. 1), and the sampling protocols follow the GAW recommendations (WMO/GAW, 2016). The aerosol intake is at a height of $10 \mathrm{~m}$ above the ground, and the particles are pulled down a $20 \mathrm{~cm}$ diameter vertical tube at a flow rate of $1000 \mathrm{~L} \mathrm{~min}^{-1}$. The particles in the center of the air stream pass through a $2.5 \mathrm{~cm}$ diameter stainless steel tube which is heated, as needed, to maintain a relative humidity (RH) of no more than $40 \%$ at a 
Table 1. Various instruments used in this comparison study.

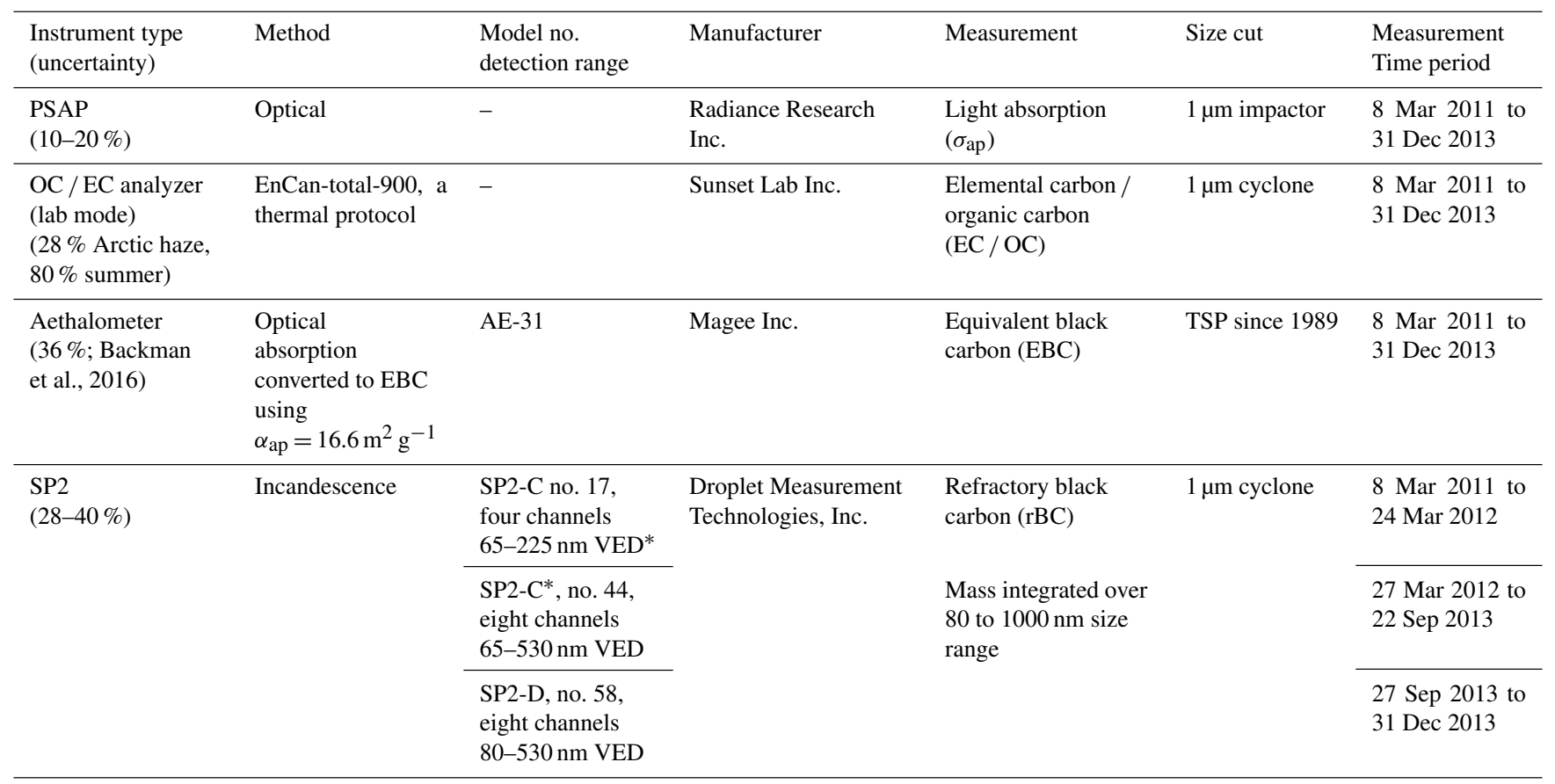

\footnotetext{
* VED is volume equivalent diameter.
}

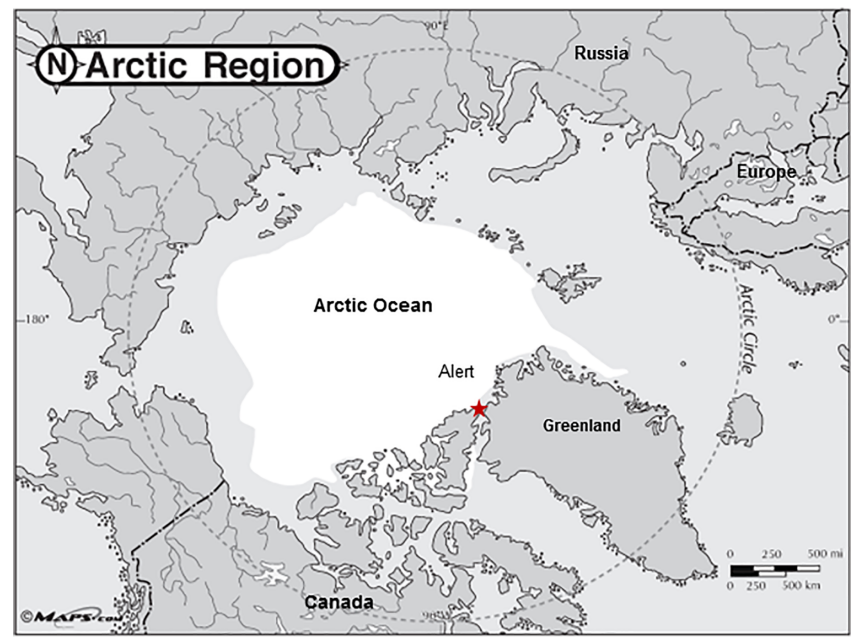

Figure 1. Alert (red star) is located at the northwest tip of Ellesmere Island in Nunavut, Canada, at $82^{\circ} \mathrm{N}$ and $62.5^{\circ} \mathrm{W}$ at an altitude of 186 m a.s.l.

flow rate of $120 \mathrm{~L} \mathrm{~min}^{-1}$. The flow is further split into four 0.75 in. $(1.9 \mathrm{~cm})$ diameter stainless steel tubes. The flows for all measurements discussed here are drawn from this common inlet. Table 1 provides a list of all instruments.

\subsection{Optical measurements}

The optical measurements of light absorption by the aerosol particles require corrections due to scattering and absorption effects from the filter media and particle loading of the filters. Further, conversion of the light absorption estimate to a $\mathrm{BC}$ mass concentration requires knowledge of the value of the MACs. The MACs will vary depending on the morphology of the $\mathrm{BC}$ component of the particle as well as the nature of the other components in the particle (Bond et al., 2013). As a consequence of the indirect nature of this BC estimate, it is referred to as EBC. Here, EBC is derived from the Aethalometer only. Light absorption measurements are taken by the PSAP.

\subsubsection{Aethalometer measurements of EBC}

EBC mass is estimated from particle light absorption measured with a Magee Scientific AE-31 Aethalometer (Hansen et al., 1984). The Aethalometer measures the real-time attenuation of light transmitted through particles accumulating on a quartz fiber filter (reinforced quartz fiber tape) at seven wavelengths. Measurements are accumulated at $5 \mathrm{~min}$ intervals. A vacuum pump draws air through the instrument so that the particles continuously accumulate on the filter while being illuminated. The effective operational wavelengths of the Aethalometer are 370, 470, 520, 590, 660, 880, and $950 \mathrm{~nm}$. The EBC measurements used here are based on the $880 \mathrm{~nm}$ wavelength to minimize potential interference 
from other absorbing components (e.g., BrC). The use of the $880 \mathrm{~nm}$ wavelength also maintains continuity with historical EBC data measured by a single $880 \mathrm{~nm}$ wavelength Aethalometer used in Alert from 1989 to 2009 (e.g., Sharma et al., 2004, 2006, 2013).

The intensity of light transmitted through the filter is measured by two photodiodes: one through the sample spot $\left(I_{\mathrm{s}}\right)$ and the other through a blank (unsampled) portion of the filter called the reference spot $\left(I_{\mathrm{r}}\right)$. The filter attenuation is defined as

$\mathrm{ATN}=-\ln \left(\frac{I_{\mathrm{s}}}{I_{\mathrm{r}}}\right)$.

The change in attenuation is obtained as a function of time and relates to the $\mathrm{EBC}$ concentration as follows:

$$
\begin{aligned}
\sigma_{\text {atn }} & =-\frac{A}{Q} \frac{\left(\operatorname{ATN}\left(t_{2}\right)-\operatorname{ATN}\left(t_{1}\right)\right)}{\left(t_{2}-t_{1}\right)}, \\
\mathrm{EBC} & =-\frac{\sigma_{\mathrm{atn}}}{\alpha_{\mathrm{ap}}},
\end{aligned}
$$

where $\operatorname{ATN}(t)$ is the filter attenuation at times $t_{1}$ and $t_{2}$ (in seconds); $Q\left(\mathrm{~m}^{3} \mathrm{~s}^{-1}\right)$ is the sample flow rate through the filter; $A\left(\mathrm{~m}^{2}\right)$ is the area of the exposed spot on the filter; $\sigma_{\text {atn }}$ is the attenuation coefficient, and $\alpha_{\text {ap }}$ is the specific attenuation coefficient $\left(\mathrm{m}^{2} \mathrm{~g}^{-1}\right)$. The manufacturer's recommended value for $\alpha_{\text {ap }}$ is $14625 / \lambda$, which is based upon calibrations during instrument development and theoretical calculations. It has a value of $16.6 \mathrm{~m}^{2} \mathrm{~g}^{-1}$ at $\lambda=880 \mathrm{~nm}$. This accounts for absorption by $\mathrm{BC}$ and additional light attenuation assumed to be caused by multiple scattering within the filter media. There are no other scattering or loading corrections applied to the Aethalometer data because a comparison of unmodified EBC mass to the best estimate of BC mass values are also determined in this paper. It is further determined how well an enhancement in the absorption due to the total scattering has been compensated by using a higher $\alpha_{\text {ap }}$ value used by the Aethalometer firmware. This is further discussed in Sect. 4.1.1. The detection limit of the Aethalometer is dependent on the stability of the optics. Changes in the light intensity correspond to a noise level of $2 \mathrm{ng} \mathrm{m}^{-3}$. Taking twice the standard deviation in the noise, we report a detection limit of $4 \mathrm{ng} \mathrm{m}^{-3}$ for a $1 \mathrm{~h}$ integration time estimated from bench zeros run at the Environment and Climate Change Canada (ECCC) laboratory for 3 days of particle-free air and a value of $2.2 \mathrm{ng} \mathrm{m}^{-3}$ for $1 \mathrm{~h}$ integration time as estimated from bench zeros in Alert as also used in the Backman et al. (2016) analysis.

\subsubsection{PSAP for light absorption}

The PSAP utilizes a similar principle in its operation as the Aethalometer (Bond et al., 1999), measuring aerosol absorption at three wavelengths $(467,530$, and $660 \mathrm{~nm})$. An algorithm for correcting the attenuation coefficient measured by the PSAP to the aerosol absorption coefficient, $\sigma_{\text {ap }}$, was derived by Bond et al., 1999) and further refined by Ogren (2010):

$\sigma_{\text {ap }}=0.85 \frac{f(\tau) \sigma_{\mathrm{atn}}}{K_{2}}-\frac{K_{1} \sigma_{\mathrm{sp}}}{K_{2}}$,

where $\sigma_{\mathrm{sp}}$ is the aerosol light scattering coefficient adjusted to the wavelength of the absorption measurement. The transmittance correction term is defined as $f(\tau)=(1.0796 \tau+$ $0.71)^{-1}$, where $\tau=\left(I_{\mathrm{S}}(t) / I_{\mathrm{r}}(t)\right) /\left(I_{\mathrm{S}}(t=0) / I_{\mathrm{r}}(t=0)\right)$ is the filter transmittance at time $t$ relative to the unsampled filter at time $t=0$. The constants in Eq. (4) were derived by Bond et al. (1999) as $K_{1}=0.02 \pm 0.02$ and $K_{2}=1.22 \pm 0.20$. Aerosol light scattering, $\sigma_{\text {sp }}$, was measured in Alert by using a TSI nephelometer at three different wavelengths; 450, 550, and $700 \mathrm{~nm}$. The truncation error of the nephelometer, which is due to an angular integration restriction to 7 and $170^{\circ}$ (Anderson and Ogren, 1998), was estimated and applied to the scattering measurements. The scattering correction was applied to the absorption measurements as shown in Eq. (4).

The PSAP absorption measurements at $530 \mathrm{~nm}$ have been converted to $550 \mathrm{~nm}$ absorption by using the $(\lambda)^{-1}$ relationship to the wavelength as particles measured are less than $1 \mu \mathrm{m}$ for this study. The exposed spot on which the sample is collected is $0.5 \mathrm{~cm}$ in diameter for the PSAP, compared to $1.1 \mathrm{~cm}$ for the Aethalometer. The detection limit for the PSAP, defined as the noise level for a $60 \mathrm{~s}$ sampling interval, was determined to be $0.2 \mathrm{Mm}^{-1}$ for a 1 min integration time (twice the standard deviation). The hourly detection limit is estimated to be $0.08 \mathrm{Mm}^{-1}$. This was determined at the site with regular $2 \mathrm{~h}$, weekly zero checks by passing particle-free air through all instruments including the PSAP. Adjustments for changes in the flow and spot area have been applied to the data.

\subsection{Single particle soot photometer for $\mathrm{rBC}$}

Measurements of $\mathrm{rBC}$ in single particles were obtained using an SP2 (Droplet Measurement Technologies, Inc., Boulder, $\mathrm{CO})$. The rBC data were collected from three different models of SP2 instruments during three different time periods as given in Table 1. No discontinuities are evident in the data before and after the instrument changes.

The detailed operating principles of an SP2 have been described previously (Stephens et al., 2003; Baumgardner et al., 2004; Schwarz et al., 2006); therefore, only a brief overview is given here. Particles are directed into the SP2, where they intersect a continuous, high-intensity $\left(1 \mathrm{MW} \mathrm{cm}^{-2}\right)$, intracavity Nd:YAG laser beam, operating at $1064 \mathrm{~nm}$. Particles intersecting the laser beam can both scatter and absorb light. Particles with a component that absorbs at $1064 \mathrm{~nm}$ are heated and begin to incandesce as they absorb the incident radiation. The $\mathrm{rBC}$ mass concentration of a single particle is determined from the strength of the incandescence signal based on a calibration using Aquadag (provided by Droplet 
Measurements Technologies, Inc., Boulder, CO) particles of known size. For the calibration, a suspension of Aquadag in water is atomized and dried, and the dried Aquadag particles are size selected with a differential mobility analyzer (Schwarz et al., 2010). On-site calibrations were conducted for all instruments. The mobility diameter of the calibration particles was converted to $\mathrm{rBC}$ mass using the parameterization developed by Gysel and colleagues (Gysel et al., 2011). Recent studies have shown that the SP2 is more sensitive to Aquadag than it is to other types of black carbon and calibrations with Aquadag can underestimate the ambient $\mathrm{rBC}$ mass concentration (Laborde et al., 2012; Moteki and Kondo, 2010). To account for this, the Aquadag calibration curves were scaled by a factor of $0.70 \pm 0.05$ based on the work of Laborde et al. (2012). They determined this scaling factor based on the relative sensitivity of the SP2 to Aquadag compared with $\mathrm{rBC}$ from denuded ambient particles from diesel and wood smoke. An example of the calibration curves for SP2 no. 58 (both low-gain and high-gain channels) is shown in Fig. 2 for soot particle masses up to $41 \mathrm{fg}$. The figure includes combined data from four calibrations carried out on 6 November 2012, 30 August 2014, 11 April 2015, and 1 December 2015.

For comparison to the $1 \mu \mathrm{m}$ sample size cuts used in front of the filters for thermal analysis (EC) and the PSAP measurements, the $\mathrm{rBC}$ mass over the range of $80-1000 \mathrm{~nm}$ was estimated by fitting a single log-normal distribution to each measured particle mass distribution. As an example, Fig. 3a and $\mathrm{b}$ show the seasonally averaged $\mathrm{rBC}$ mass and number distributions and the fitted distributions. In this example, the measurements, indicated by the circles, are limited to $333 \mathrm{~nm}$ volume equivalent diameter (VED) due to the averaging involving the four-channel SP2 (no. 17). Overall, the fitted distributions are reasonable approximations. The discontinuities are associated with the mixing of the different instruments and years in deriving these averaged curves. The number distributions are estimated from the fits to the mass distribution and will be discussed in Sect. 3.2.1.

\subsection{Thermal method (EnCan-total-900) for EC}

Weekly integrated samples of particles collected on quartz filters with a $1 \mu \mathrm{m}$ upper size cut were analyzed for EC and $\mathrm{OC}$ using an in-house thermal technique referred to as EnCan-total-900. This technique was originally developed for carbon isotope analysis of OC and EC (Huang et al., 2006). This method differs from the thermal-optical methods used in the Interagency Monitoring of Protected Visual Environments (IMPROVE) network (e.g., Chow et al., 2001) and by the National Institute for Occupational Safety and Health (NIOSH, 1996, 1999), as it does not incorporate laser reflectance or transmittance but only temperature and retention time used to determine OC and EC. The EnCan-total900 technique involves three temperature-dependent steps. The first two steps occur under a pure helium condition at

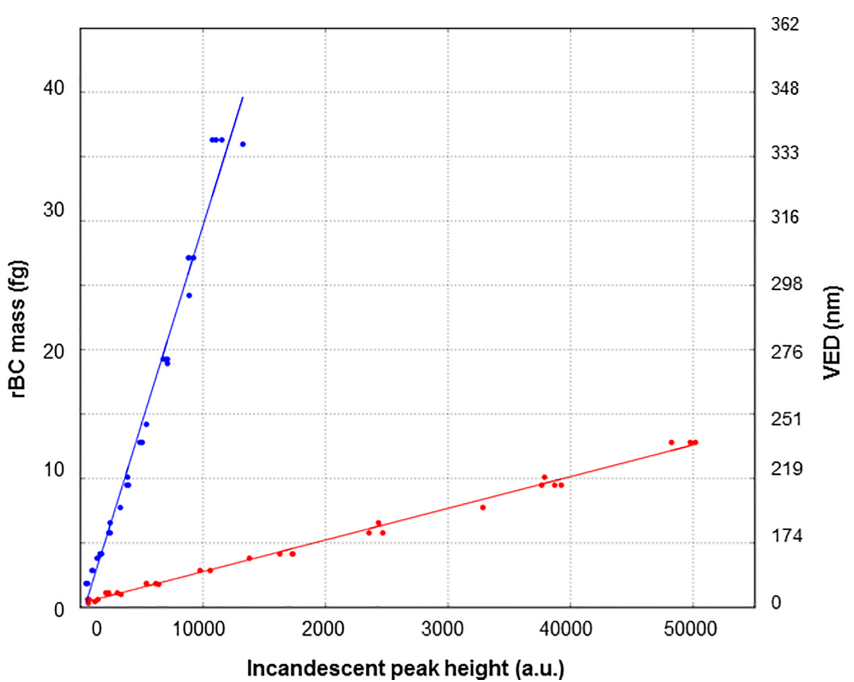

Figure 2. A calibration curve for SP2 no. 58 shows an incandescent peak height with an arbitrary unit response to $\mathrm{rBC}$ mass (fg). The data points in blue circles apply to the low-gain channel and those in red circles to the high-gain channel. The right-hand axis shows the volume equivalent diameter (VED) in nanometers.

$550{ }^{\circ} \mathrm{C}$ for the detection of $\mathrm{OC}$ and at $870^{\circ} \mathrm{C}$ for the detection of pyrolysis $\mathrm{OC}$ (POC) and carbonate carbon (CC). $\mathrm{EC}$ is detected at $900^{\circ} \mathrm{C}$ under helium and $10 \%$ oxygen. Compared to the IMPROVE and NIOSH methods, the retention times at each step are much longer: 600,600, and $420 \mathrm{~s}$ at 550,870 , and $900^{\circ} \mathrm{C}$, respectively. By introducing the $870^{\circ} \mathrm{C}$ pure helium phase, the POC and CC are released such that the effect of OC charring on EC is minimized. An example thermograph from the analysis of a NIST standard (SRM8785 urban dust) is shown in Fig. 4. Repeated measurements of SRM8785 over 6 years indicate an uncertainty in the EC measurements of $<10 \%$ for this urban dust aerosol. EC determined by thermal and thermal-optical methods is dependent on the methodology to some degree. An interlaboratory comparison among different methods used in longterm atmospheric observation networks showed the relative standard deviation of the mean value of EC measurements in an intercomparison effort by the three protocols, i.e., the IMPROVE, EUSAAR and EnCan-total-900 to be $25 \%$ (Karanasiou et al., 2015). Also, the EnCan-total-900 method has been verified by comparing the mass fractions of OC, EC, POC, and $\mathrm{CC}$ with the corresponding weighed amounts. The measurements of isotopic compositions $\left({ }^{13} \mathrm{C} /{ }^{12} \mathrm{C}\right.$ and $\left.{ }^{14} \mathrm{C} /{ }^{12} \mathrm{C}\right)$ indicate quantitative separation of $\mathrm{OC}$ and $\mathrm{EC}$ (Huang et al., 2015). 

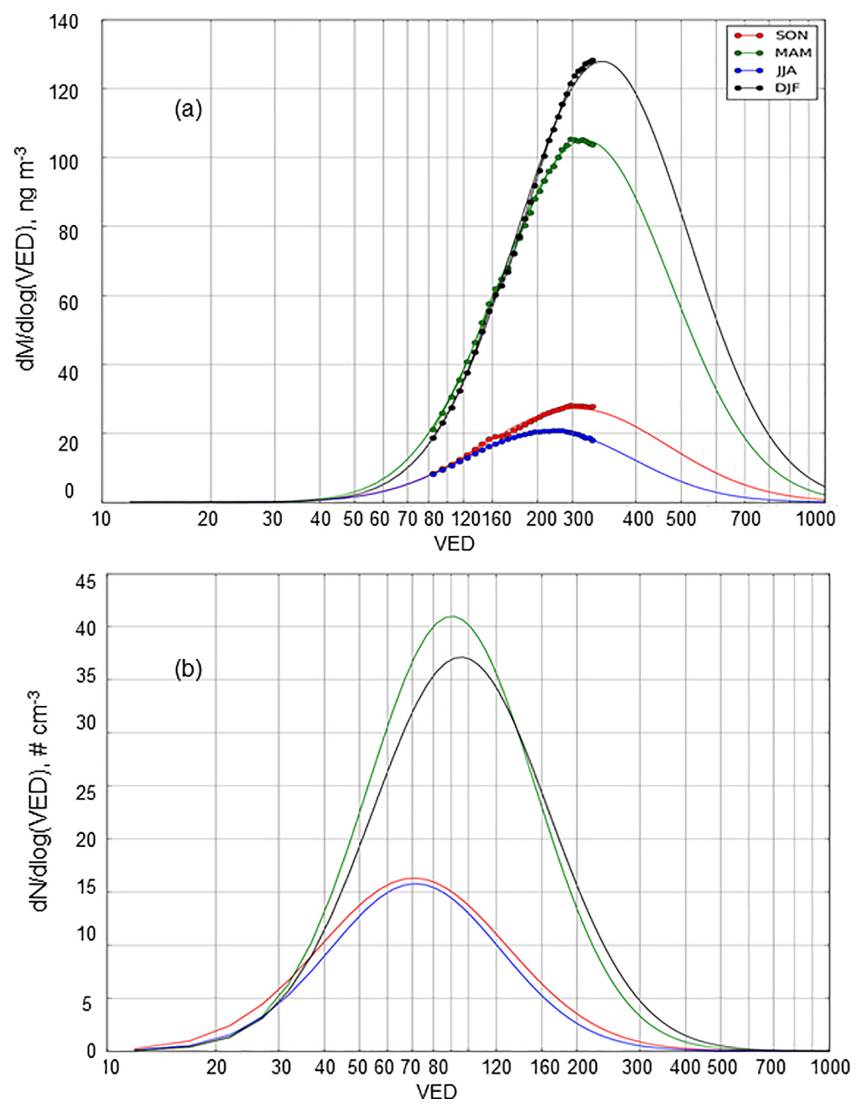

Figure 3. Seasonally averaged mass (a) and number (b) distributions, by volume equivalent diameter (VED), of rBC particles detected by the SP2 in Alert, NU, from March 2011 to December 2013. The number distributions are estimated from the fits to the mass distribution. The black, green, blue, and red data curves represent the 3-month average season: winter (DJF), spring (MAM), summer (JJA), and fall (SON), respectively. On average, a modal mass diameter at $225 \mathrm{~nm}$ was measured for $\mathrm{rBC}$ during winter and around $170 \mathrm{~nm}$ during summer. The number distribution shows a mode at $100 \mathrm{~nm}$ during winter due to long-range transport influence and during the light period in the spring, giving a smaller particle diameter. VED indicates volume equivalent diameter. The solid circles represent the size range of calibration.

\subsection{Uncertainties in the measurement techniques}

\subsubsection{Aethalometer}

The relative uncertainty of the measured light attenuation coefficient is defined by Backman et al. (2016):

$\frac{\delta \sigma_{\mathrm{atn}}}{\sigma_{\mathrm{atn}}}=\sqrt{\left(\frac{\delta \Delta \mathrm{ATN}^{2}}{\Delta \mathrm{ATN}^{2}}\right)+\frac{\delta A^{2}}{A^{2}}+\frac{\delta Q^{2}}{Q^{2}}}$.

Backman et al. (2016) estimate that for $\Delta \mathrm{ATN} \geq 2 \%$ a relative uncertainty at $880 \mathrm{~nm}$ in Alert is $2.5 \%$ (for noise only) in a $24 \mathrm{~h}$ time period. The uncertainty in flow rate is $1.5 \%$ as reported by the manufacturer of the flow controller and $2 \%$

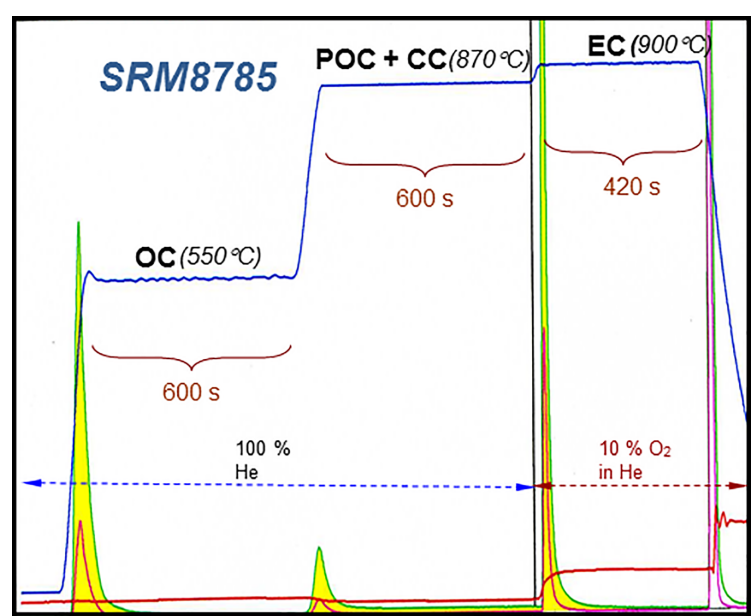

Time (s)

Figure 4. Typical thermograph of the NIST standard (SRM8785: urban dust on filter) using the thermal method (EnCan-total-900). The solid dark blue line indicates the temperature time series. The green and red peaks highlighted in yellow are two flame ionization detector signals (one with higher sensitivity than the other). The solid red line is the laser transmittance; however, it is not relevant here since transmittance is not used to determine the OC and EC concentration. The determinations of the $\mathrm{OC}, \mathrm{POC}+\mathrm{CC}$, and $\mathrm{EC}$ mass fractions are purely based on temperature and retention time.

for the spot size can be achieved by digital image analysis. Backman et al. (2016) estimated $36 \%$ relative uncertainty of the instrument including the drift. There are uncertainties in $\sigma_{\text {atn }}$ for the Aethalometer due to particle loading and scattering that cannot be determined for this study. A constant $\alpha_{\text {ap }}$ value of $16.6 \mathrm{~m}^{2} \mathrm{~g}^{-1}$ is used to estimate black carbon mass from the Aethalometer measurements. It has been shown that there can be large uncertainties in the $\alpha_{\text {ap }}$ value (e.g., Liousse et al., 1993; Sharma et al., 2002).

\subsubsection{PSAP}

The main sources of uncertainty in the light absorption measurement from the PSAP are the measurement of the instrumental noise $\Delta \sigma_{\text {ap } \text {,noise }}$ sample spot size, the flow calibration $\Delta \sigma_{\text {ap,flow,spotsize }}$, and the uncertainty $\Delta \sigma_{\text {ap,cal }}$ of the calibration constants $K_{1}$ and $K_{2}$ in the Bond et al. (1999) correction (Eq. 4). The combined uncertainty for the PSAP measurements is

$\Delta \sigma_{\mathrm{ap}}^{2}=\left(\Delta \sigma_{\mathrm{ap}, \text { cal }}^{2}+\Delta \sigma_{\mathrm{ap}, \text { flow, spotsize }}^{2}+\Delta \sigma_{\mathrm{ap}, \text { noise }}^{2}\right)$.

The standard deviation in the $1 \mathrm{~min}$ and $1 \mathrm{~h}$ absorption data for particle-free air in Alert are 0.14 and $0.005 \mathrm{Mm}^{-1}$ at $550 \mathrm{~nm}$ wavelength. The combined uncertainty, $\Delta \sigma_{\text {ap,flow,spotsize }}$, depends on the uncertainty in the flowmeter calibration $(1.5 \%)$ and measurement of spot size $(2 \%)$. 
Sherman et al. (2015) showed that the uncertainty in absorption depends on the uncertainty in the $\mathrm{K} 1$ and $\mathrm{K} 2$ values in the Bond et al. (1999) correction. Equation (4) is rewritten in Eq. (7) in terms of the single scattering albedo, $\omega_{0}=\left(\sigma_{\mathrm{sp}} /\left(\sigma_{\mathrm{sp}}+\sigma_{\mathrm{ap}}\right)\right)$.

$\sigma_{\mathrm{ap}}=\frac{\sigma_{\mathrm{ap}, \mathrm{meas}}}{a \times K_{1}+K_{1}}$,

where $a=\omega_{0} /\left(1-\omega_{0}\right)$ and $\sigma_{\text {ap, meas }}=\sigma_{\text {atn }} \times f(\tau)$ as defined above. The uncertainty in $\sigma_{\text {ap }}$ from the calibration constants is given by

$\Delta \sigma_{\mathrm{ap}, \mathrm{cal}}=\left(\left(\frac{\partial \sigma_{\mathrm{ap}}}{\partial K_{1}} \times \Delta K_{1}\right)^{2}+\left(\frac{\partial \sigma_{\mathrm{ap}}}{\partial K_{2}} \times \Delta K_{2}\right)^{2}\right)^{\frac{1}{2}}$.

Equation (8) can be rewritten as follows:

$$
\begin{aligned}
\Delta \sigma_{\mathrm{ap}, \mathrm{cal}}= & \frac{\sigma_{\mathrm{ap}, \text { meas }}}{\left(0.02 \times \frac{\omega_{0}}{1-\omega_{0}}+1.44\right)^{2}} \\
& \times\left(\left(0.02 \times \frac{\omega_{0}}{1-\omega_{0}}\right)^{2}+(0.24)^{2}\right)^{\frac{1}{2}},
\end{aligned}
$$

where $K_{1}=0.02 \pm 0.02$ and $K_{2}=1.22 \pm 0.20$ and the uncertainties in the calibration constants are $\Delta K 1=0.02$ (Bond et al., 1999) and $\Delta K 2=0.24$ (from Bond et al., 1999, with Ogren, 2010, adjustment).

In Alert, $\omega_{0}$ calculated from the measurements ranges less than 1 and 0.95 . For a $\omega_{0}$ of 0.95 and light absorption values ( $\left.\sigma_{\mathrm{ap}, \text { meas }}\right)$ of 0.5 and $1 \mathrm{Mm}^{-1}$ (as typical for Alert), Eq. (9) defines an uncertainty in the absorption coefficient, which has been calculated to be between 0.099 and $0.11 \mathrm{Mm}^{-1}$ (i.e., 10-20\%), respectively.

Weekly zeroes are performed on the PSAP in Alert by flushing particle-free air for a time period of 1 to $2 \mathrm{~h}$ through the instrument. During this process, the uncertainty in the measurement due to instrumental noise was determined.

\subsubsection{SP2}

Uncertainty in the rBC mass derived from the SP2 measurements arises from several sources. As described in Sect. 2.2 mass calibration for all three SP2s was carried out using Aquadag as an external standard. Uncertainties in the slopes of the Aquadag calibration curves give rise to uncertainty in the rBC mass calculated for each detected particle. This uncertainty is dependent on the individual particle size and ranges from around $5 \%$ for the largest particles to around $35 \%$ for the smallest particles (based on the calibration with the largest uncertainty). When the individual particle masses are combined to give a $1 \mathrm{~h}$ mass concentration, the overall mass uncertainty arising from the calibration curves is on average 12,11 , and $16 \%$, for SP2 nos. 58, 44, and 17, respectively.
Another uncertainty in the rBC mass arises from using Aquadag as a standard. Due to the SP2's enhanced sensitivity to Aquadag (discussed in Sect. 2.2), the calibration curves were scaled by dividing by a factor of $0.70 \pm 0.05$. After this correction is applied, the combined $1 \mathrm{~h}$ mass concentration uncertainty (arising from the uncertainty in the fits of the calibration curves and from the uncertainty in the Aquadag correction) is 19,18 , and $23 \%$ for SP2 nos. 58,44 , and 17 , respectively.

Additionally, there is an uncertainty of approximately 12, 7, and $15 \%$ for SP2 nos. 58, 44, and 17, respectively, which arises from the process of fitting the mass distribution and using this fit to estimate how much $\mathrm{rBC}$ mass lies outside the instrument detection range. This results in overall mass uncertainties in the range of $25-38 \%$ depending on the instrument used.

In some cases calibrations were not carried out over the full detection range of the instrument and had to be extrapolated to higher $\mathrm{rBC}$ masses. Uncertainty from this extrapolation is not accounted for; however, the linear correlations between $\mathrm{rBC}$ mass and peak height are relatively strong (as shown in Fig. 2), suggesting that this is not a large source of error.

\subsubsection{Thermal technique}

The EC mass concentration from the filter analyses is calculated as follows:

$C=X \times \frac{A}{V}$,

where $X$ is the area concentration $\left(\mu \mathrm{g} \mathrm{cm}^{-2}\right)$ of the filter punch analyzed by the OC-EC analyzer (Sunset Lab Inc., http://www.sunlab.com), A is the sampling area $\left(\mathrm{cm}^{2}\right)$ of a quartz filter with a diameter of $47 \mathrm{~mm}$ (Pall Corporation, Analyslide ${ }^{\mathrm{TM}}$ Petri Dishes), $V$ is the total integrated air volume $\left(\mathrm{m}^{3}\right)$ sampled through the filter, and $C$ is the concentration of the integrated air sample on the filter $\left(\mu \mathrm{g} \mathrm{C} \mathrm{cm}^{-3}\right)$. The relative uncertainty is estimated by

$$
\begin{aligned}
& \frac{\partial C}{C}= \\
& \sqrt{\left(\frac{\partial X}{X_{i}}\right)^{2}+\left(\frac{\partial B}{X_{i}}\right)^{2}+\left(\frac{\partial A}{A}\right)^{2}+\left(\frac{\partial V}{V}\right)^{2}+\left(\frac{\partial X_{\text {dup }}}{A X_{\text {dup }}}\right)^{2}},
\end{aligned}
$$

where $\left(\frac{\partial X}{X_{i}}\right)$ is the relative uncertainty of instrument measurement for carbon mass, based on the accuracy and precision determined by the calibrations over the period of 2010 to 2016, using a gravimetric approach on a sucrose standard; $\left(\frac{\partial B}{X_{i}}\right)$ is the relative uncertainty of EC contributed from the field blank; $\left(\frac{\partial A}{A}\right)$ is the relative uncertainty of the sampling area; $\left(\frac{\partial V}{V}\right)$ is the relative uncertainty of the total sampled air volume; and $\left(\frac{\partial X_{\text {dup }}}{A X_{\text {dup }}}\right)$ is the relative uncertainty of the EC 
due to sampling inhomogeneity, based on duplicated analysis across the entire network. Among the five components, $\left(\frac{\partial X}{X_{i}}\right),\left(\frac{\partial A}{A}\right),\left(\frac{\partial V}{V}\right)$, and $\left(\frac{\partial X_{\text {dup }}}{A X_{\text {dup }}}\right)$ are the same for all the samples: $0.05,0.07,0.01$, and 0.1 , respectively. While the term $\left(\frac{\partial B}{X_{i}}\right)$ is dependent on individual samples, the mean relative uncertainty of the EC measurements in Alert over the period of March 2011 to December 2013 is approximately $28 \%$ and can be as high as $80 \%$ during summer due to very low EC concentrations.

\section{Results}

\subsection{Time series and seasonal variation of masses of rBC, EBC, and EC}

The time series of the mass concentrations of $\mathrm{rBC}, \mathrm{EBC}$, and EC for March 2011 to December 2013 are shown in Fig. 5a$\mathrm{c}$, where $\mathrm{EBC}$ is derived from the Aethalometer at a wavelength of $880 \mathrm{~nm}$. The $\mathrm{rBC}$ and EBC data are hourly averages, while the EC data are weekly integrated values. Over the study period, the mean $\mathrm{rBC}, \mathrm{EBC}$, and $\mathrm{EC}$ are 17, 38, and $29 \mathrm{ng} \mathrm{m}^{-3}$, respectively. Figure $5 \mathrm{~d}$ shows the $\mathrm{rBC}$ and $\mathrm{EBC}$, after averaging to the EC weekly integrated times and subsequently monthly averages, with the monthly averaged EC. The monthly averaged $\mathrm{rBC}$ concentrations are lowest, $\mathrm{EBC}$ are highest, and EC falls in between except for the summer (JJA), when EC is highest. The higher winter and spring values are the result of pollution transported to the Arctic from various anthropogenic sources at lower latitudes, a phenomenon often referred to as Arctic haze (e.g., Barrie, 1986; Sharma et al., 2006; Quinn et al., 2007; Stone et al., 2015). Summertime concentrations are much lower than other seasons largely due to wet scavenging (e.g., Garrett et al., 2011; Croft et al., 2016). Previous characterizations of the pollution source regions influencing Alert indicate the potential source contribution function highest for Western Siberia followed by Europe and a very small influence at the surface from North America and Eastern Asia during winter and spring (Sharma et al., 2004, 2006, 2013; Gong et al., 2010; Hirdman et al., 2010). More recently, global simulations suggest a broad influence of Eastern Asia in Alert that is strongest during spring and has a long transport time (Xu et al., 2017; Qi et al., 2017).

Seasonal averages of all measurements and their 25th and 75th percentiles are given in Table 2 to show how all techniques respond to seasonal variation of the atmospheric changes in black carbon levels. The average EBC masses are significantly higher than the $\mathrm{rBC}$ masses $(p<0.01)$ for all seasons by approximately a factor of 2 . Slopes intercepts and standard errors, coefficients of determination, and significance levels for linear regressions among $\mathrm{EC}, \mathrm{rBC}$, and $\mathrm{EBC}$ are given in Table 2. All results are significant at the
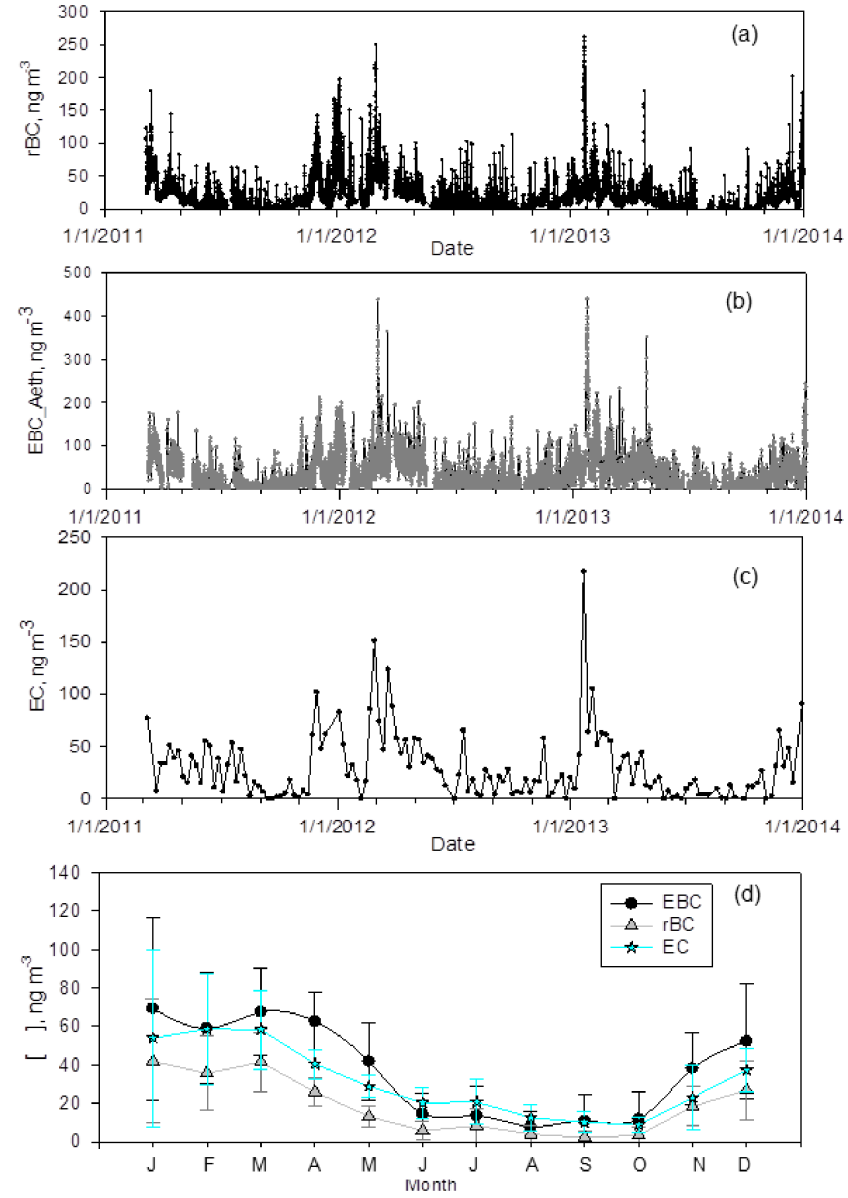

Figure 5. The temporal variation of BC in Alert, NU, from March 2011 to December 2013: (a) hourly refractory BC, (b) hourly equivalent BC from the Aethalometer at $880 \mathrm{~nm}$, (c) weekly EC concentrations, and (d) monthly averaged mass of each technique and standard deviation.

$95 \%$ confidence level with the exception of winter EBC vs. EC.

Table 3 gives mean $\pm \mathrm{SD}$ and median values of $\mathrm{EC}, \mathrm{rBC}$, and $\mathrm{EBC}$ for the entire study period to elucidate the differences in the techniques. Statistics are given for all data, data only above detection limit, and only for pairwise data available, i.e., data when both variables were available for comparison. The ratios of $\mathrm{EBC}$ and $\mathrm{EC}$ to $\mathrm{rBC}$ concentrations are approximately a factor of 3 higher for all data when only pairwise data points were considered.

Before discussing possible reasons for the differences among $\mathrm{EBC}, \mathrm{EC}$, and $\mathrm{rBC}$, the $\mathrm{rBC}$ number size distributions and thicknesses of coatings associated with $\mathrm{rBC}$ particles as derived from the SP2 measurement are examined. 


\section{2 $\mathrm{rBC}$ number size distributions and $\mathrm{rBC}$ coating thicknesses}

\subsection{1 rBC number distributions}

The $\mathrm{rBC}$ number distributions derived from the curves fitted to the $\mathrm{rBC}$ mass distributions are shown in Fig. 3b, using a density assumption for the ambient $\mathrm{rBC}$ of $1.8 \mathrm{~g} \mathrm{~cm}^{-3}$ from Bond and Bergstrom (2006). Relative to the mass distributions, the uncertainty in the number distributions is greater below the lower limit of $80 \mathrm{~nm}$ than above the upper limit of $530 \mathrm{~nm}$. Comparisons of the seasonal number distributions indicate that both the mean concentrations and sizes of the $\mathrm{rBC}$ components of particles are larger during winter-spring than summer-fall. This pattern is consistent with increased wet scavenging of larger particles during summer-fall seasons (Garrett et al., 2011; Sharma et al., 2013).

\subsection{2 rBC coating thicknesses}

BC particles are often coated by other components (e.g., sulphate and organics, water) that can enhance the absorption by $\mathrm{BC}$ by increasing the light intercepted by the particle, sometimes referred to as a "lensing effect" (e.g., Bohren and Huffman, 1983; Isaac et al., 1986; Cross et al., 2010; Shiraiwa et al., 2010). Shiraiwa et al. (2010) showed that even small coatings $\left(D_{\mathrm{p}} / D_{\mathrm{c}}=1.2\right.$, where $D_{\mathrm{p}}$ is the outer particle diameter and $D_{\mathrm{c}}$ is the diameter of the core $\mathrm{BC}$ component, based on the core-shell concept) may result in an amplification of absorption of as much as 1.3 , and the amplification for a $D_{\mathrm{p}} / D_{\mathrm{c}}$ of 2 is about 2. Thus, it is important to know the thickness of material coating the $\mathrm{BC}$ components, in addition to the index of refraction of the coating. To derive the coating thickness from the SP2 measurements, the scattering signal from incandescent particles must first be reconstructed, for which the leading edge optimization method of Gao et al. (2007) was used. Using Mie theory and assuming a core-shell model, the thickness of the coating present on the $\mathrm{rBC}$ core was calculated based on the measured scattering signal in conjunction with the measured $\mathrm{rBC}$ mass. The refractive index used for the core is $2.26-1.26 i$ (Moteki et al., 2010; Taylor et al., 2015) and the refractive index used for the coating material is $1.5-0.0 i$ (Metcalf et al., 2012; Schwarz et al., 2008), since the calibrations of the scattering signal were done with polystyrene latex spheres (PSLs). It should be noted that the assumption of concentric core-shell morphology is a simplification for $\mathrm{rBC}$ particles in the atmosphere (e.g., Moffet et al., 2016).

The SP2 simultaneously measures incandescence and light scattering by individual particles with optical diameters in the range of approximately $200-400 \mathrm{~nm}$, enabling coating thicknesses to be calculated for a limited but significant particle size range. Typically, much of the light extinction by fine particles occurs in this size range. The period when such analysis is possible depends on the availability of light scat-

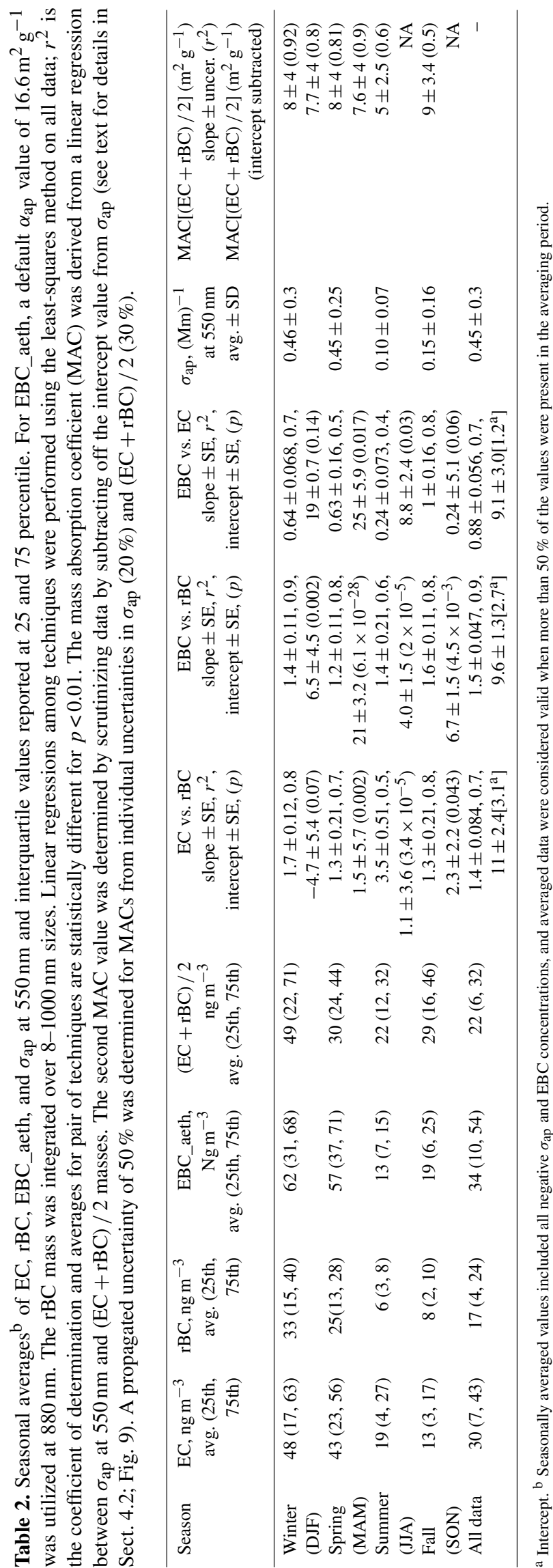

Atmos. Chem. Phys., 17, 15225-15243, 2017 
Table 3. Statistical parameters such as mean, median, and standard deviation for all data, March 2011 to December 2013, and data with only above detection limit values included. The ratios are only meaningful for the data above the detection limit values. Also pairwise statistics available for dataset when both pairs in comparison had data. In the comparison to Table 2, where all data including negative values are used in the regression analyses, Table 3 values in the first column labeled "All data conc." include negative values and are more comparable.

\begin{tabular}{|c|c|c|c|c|c|c|c|c|c|c|}
\hline & \multicolumn{2}{|c|}{$\begin{array}{l}\text { All data conc. } \\
\qquad\left(\mathrm{ng} \mathrm{m}^{-3}\right)\end{array}$} & \multicolumn{2}{|c|}{$\begin{array}{l}\text { All data conc. } \\
\quad\left(\mathrm{ng} \mathrm{m}^{-3}\right) \\
\text { (above det. lim. values) }\end{array}$} & \multicolumn{6}{|c|}{$\begin{array}{l}\text { Conc. }\left(\mathrm{ng} \mathrm{m}^{-3}\right) \text { and ratios } \\
\text { pairwise (only include data when both pairs } \\
\text { of data are available and above det. lim.) }\end{array}$} \\
\hline & \multirow[b]{2}{*}{ Mean } & \multirow[b]{2}{*}{ Median } & \multirow[b]{2}{*}{ Mean } & \multirow[b]{2}{*}{ Median } & \multicolumn{2}{|c|}{ EBC vs. rBC } & \multicolumn{2}{|c|}{ EC vs. rBC } & \multicolumn{2}{|c|}{ EC vs. EBC } \\
\hline & & & & & Mean & Median & Mean & Median & Mean & Median \\
\hline $\mathrm{EBC}$ & $34 \pm 31$ & 23 & $36 \pm 30$ & 25 & $37 \pm 31$ & 26 & - & - & $43 \pm 31$ & 32 \\
\hline $\mathrm{EC}$ & $30 \pm 32$ & 18 & $40 \pm 32$ & 32 & - & - & $40 \pm 32$ & 32 & $43 \pm 33$ & 38 \\
\hline $\mathrm{rBC}$ & $17 \pm 19$ & 11 & $17 \pm 19$ & 11 & $18 \pm 20$ & 11 & $21 \pm 20$ & 14 & - & - \\
\hline $\mathrm{EBC} / \mathrm{rBC}$ & - & - & $2.7 \pm 1.5$ & 2.2 & $2.7 \pm 1.5$ & 2.2 & - & - & - & - \\
\hline $\mathrm{EC} / \mathrm{rBC}$ & - & - & $3.1 \pm 2.6$ & 2.2 & - & - & $3.1 \pm 2.6$ & 2.3 & - & - \\
\hline $\mathrm{EC} / \mathrm{EBC}$ & - & - & $1.2 \pm 0.8$ & 1.0 & - & - & - & - & $1.2 \pm 0.8$ & 1.0 \\
\hline
\end{tabular}
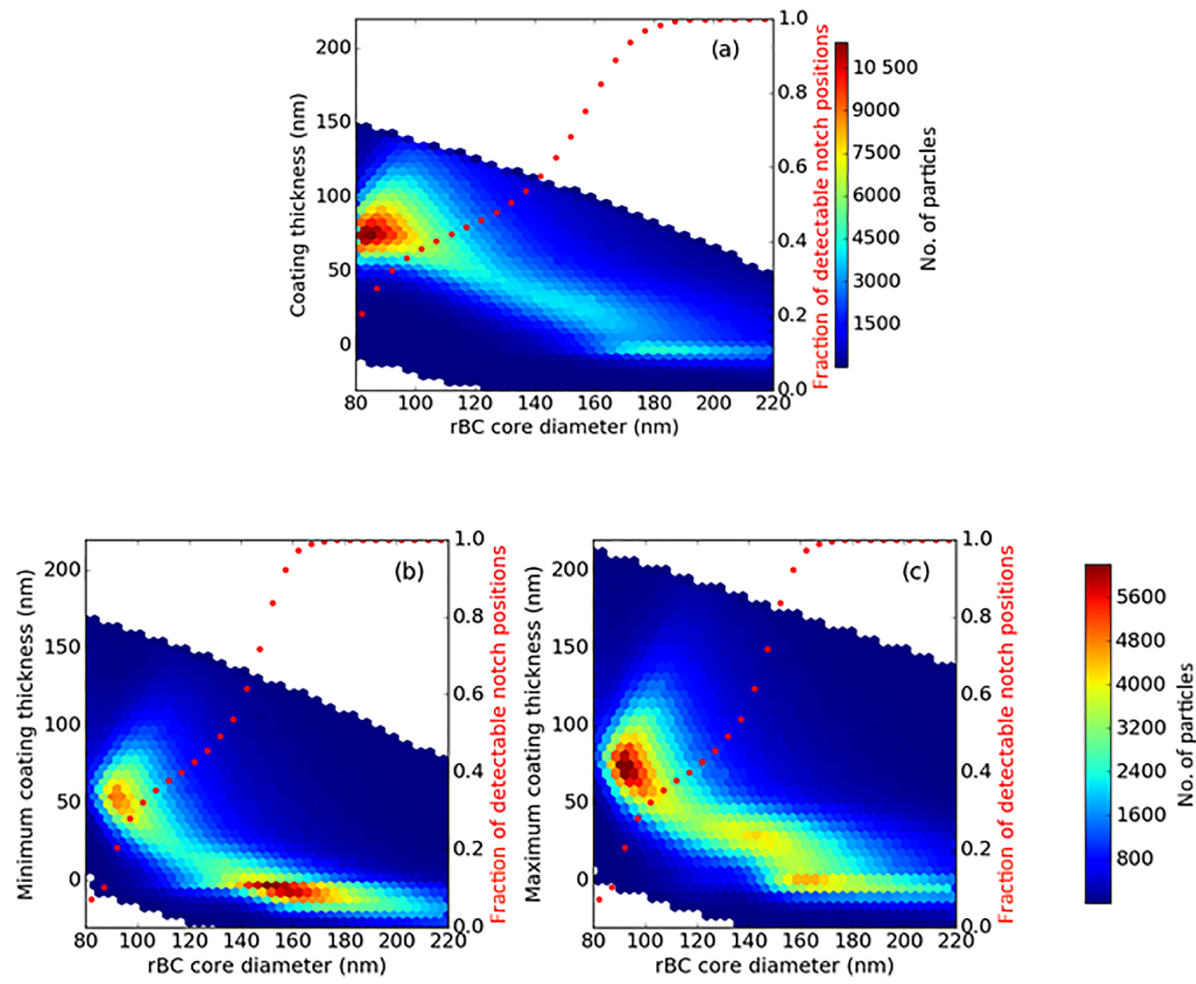

Figure 6. Two-dimensional histograms of coating thickness as a function of core size for $\mathrm{rBC}$ particles in Alert, NU: (a) the average coating thickness during April 2012, (b) the minimum coating thickness during October and November 2013, and (c) the maximum minimum coating thickness during October and November 2013. The red circles indicate what fraction of rBC cores at each size could be successfully assigned a coating thickness. Negative coating thickness indicates that the measured scattering for a particle is less than the Mie calculations predict for an $\mathrm{rBC}$ particle of that diameter with zero coating. These values arise from the inherent noise in the data, assumptions made about the $\mathrm{rBC}$ and coating refractive indices, and particle morphology.

tering calibrations; for this work, the periods of analysis are limited to April 2012 and October-November 2013. The results of the coating analyses, averaged over these two periods, are shown in Fig. 6 as a function of the rBC diameter. Figure $6 \mathrm{~b}$ shows the minimum coating thickness averaged for
October-November, and Fig. 6c shows the maximum thickness for the same period. The maximum and minimum are shown because only two scattering calibrations were done for the SP2 in use at that time: one in November 2012 and one in December 2015. During the time between the two cal- 
ibrations, there was reduction in the light scattering signal by a factor of 2 from the $240 \mathrm{~nm}$ PSL particles. Therefore, the calculations were done for each calibration under the assumption that one yields a minimum coating thickness and the other a maximum coating thickness. The red dots in each panel indicate the fraction of $\mathrm{rBC}$ cores that could have a thickness estimate assigned. This fraction decreases with decreasing size as the ability to detect light scattered from a particle also decreases. Although the incandescence measurements can size $\mathrm{rBC}$ cores down to approximately $80 \mathrm{~nm}$, the elastic scattering optics in the SP2 can only detect bare rBC cores down to approximately $115 \mathrm{~nm}$. In all panels, the apparent coating thickness increases with decreasing $\mathrm{rBC}$ core. As the $\mathrm{rBC}$ cores decrease below $115 \mathrm{~nm}$, thicker coatings are required to produce a measurable scattering signal. As a result, when the $\mathrm{rBC}$ cores are less than $115 \mathrm{~nm}$, the coating thickness is overestimated due to bias in the elastic scattering detection system toward thicker coatings.

Over the rBC size range of 160-180 nm, coating thicknesses are assigned for more than $80 \%$ of the rBC particles. Figure 7 shows the average ratio of the total particle diameter (rBC core and coating) to the $\mathrm{rBC}$ core diameter $\left(D_{\mathrm{p}} / D_{\mathrm{c}}\right)$ every $6 \mathrm{~h}$; minimum and maximum thicknesses are shown for October-November. In April 2012, there is a gradual decrease in $D_{\mathrm{p}} / D_{\mathrm{c}}$ from about 1.4 at the beginning to about 1.25 at the end of the month. This decrease may be representative, but a changing calibration cannot be ruled out. More variability is evident in October-November 2013, and the average minimum and maximum thicknesses are about 1.05 and 1.35; the maximum thickness starts at about 1.4 and decreases to about 1.3. Since the maximum thicknesses for October-November 2013 are close to the values for April 2012 , and the calibration used to derive the minimum thickness is 2 years after the measurements whereas the one used for the maximum thickness occurred 1 year before the measurements, the true thicknesses for October-November 2013 are likely closer to the maximum values. The aerosol absorption Ångström exponent (AAE) values, as discussed in the Supplement (see Fig. S1b), also suggests predominately fossil fuel sources of $\mathrm{rBC}$ and little biomass burning influence $\left(\mathrm{AAE}_{\mathrm{avg}(\mathrm{Apr} \text { and } \mathrm{Oct})}=0.75 \pm 0.12\right)$.

The present $D_{\mathrm{p}} / D_{\mathrm{c}}$ can be compared with those of other studies. In background continental air over Texas and for a $D_{\mathrm{c}}$ of $190-210 \mathrm{~nm}$, Schwartz et al. (2008) reported $D_{\mathrm{p}} / D_{\mathrm{c}}$ values about 1.5 times higher than reported here. A value of 2.4 at a $170 \mathrm{~nm}$ core size was measured in a smoke plume over Europe (Dahlkötter et al., 2014), and a study in the Finnish Arctic found a $D_{\mathrm{p}} / D_{\mathrm{c}}$ of 2 for $D_{\mathrm{c}}$ of $150-200 \mathrm{~nm}$ (Raatikainen et al., 2015). More comparable with the present results, Sahu et al. (2012) found an average $D_{\mathrm{p}} / D_{\mathrm{c}}$ of 1.5 for aged biomass burning plumes and an average $D_{\mathrm{p}} / D_{\mathrm{c}}$ of 1.24 for aged fossil fuel combustion plumes in California, where $D_{\mathrm{c}}$ was greater than $200 \mathrm{~nm}$. In six Asian cities, Kondo et al. (2011) measured a median $D_{\mathrm{p}} / D_{\mathrm{c}}$ of 1.1 for $D_{\mathrm{c}}$ of 160 $180 \mathrm{~nm}$ near the source.
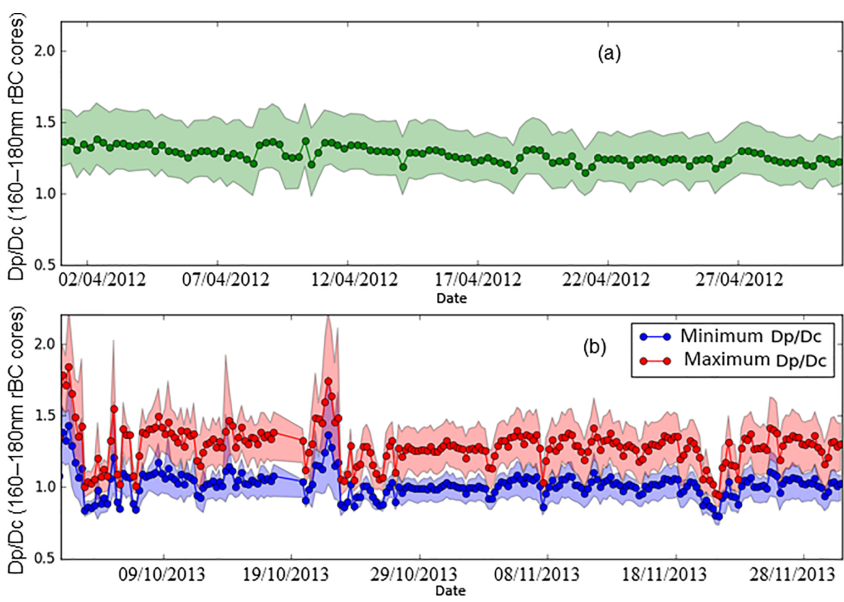

Figure 7. Time series of the mean ratio of total particle diameter (core and coating, $\left.D_{\mathrm{p}}\right)$ to $\mathrm{rBC}$ core diameter $\left(D_{\mathrm{c}}\right)$ for $(\mathbf{a})$ April 2012 and (b) October-November 2013 with the 25th and the 75th percentile represented by the shaded region. The minimum and maximum range in the $D_{\mathrm{p}} / D_{\mathrm{c}}$ are shown for the OctoberNovember 2013 period because the sensitivity of the scattering channel changed, resulting in two valid calibrations.

In Alert and over the scattering size range of $200-400 \mathrm{~nm}$, the seasonal ratios of $\mathrm{rBC}$ particle numbers (incandescent events) to total particles (scattering events) are 0.12 for DJF, 0.11 for MAM, 0.16 for JJA, and 0.10 for SON. Assuming there are no smaller undetectable $\mathrm{rBC}$ cores in the scattering particles, the percentage of particles containing $\mathrm{rBC}$ are approximately between 10 and $16 \%$, lower than the $24 \%$ found in the Finnish Arctic across the 350 to $450 \mathrm{~nm}$ size range (Raatikainen et al., 2015).

\subsubsection{Summary}

During the summer and fall seasons, number concentrations of $\mathrm{rBC}$ cores in Alert are a factor of 5-10 lower and exhibit a slightly smaller mode diameter than during winter-spring. For $\mathrm{rBC}$ cores in the $160-180 \mathrm{~nm}$ range, the average particle coating thicknesses in April 2012 and in October-November 2013 were estimated to range from 1.25 to 1.4 (this corresponds to a mass fraction of $\mathrm{rBC}$ ranging from 0.51 to 0.36 , assuming a $170 \mathrm{~nm}$ rBC core). For particles scattering light equivalent to 200-400 nm PSL particles, the proportion containing detectable $\mathrm{rBC}$ cores is between 10 and $16 \%$.

\section{Discussion}

\subsection{Best estimate of aerosol BC in Alert}

Possible reasons for the differences among the three techniques used to estimate $\mathrm{BC}$ in Alert (EC, EBC, and $\mathrm{rBC}$ ) are discussed in this section, leading to a best estimate for $\mathrm{BC}$ in 
Alert that may be useful for evaluation of chemical transport models.

\subsubsection{EBC}

EBC will overestimate $\mathrm{BC}$ if there is absorption from coexisting components and/or coatings of the rBC cores, such as BrC (e.g., Kirchstetter et al., 2004; Lack et al., 2013; Lack and Langridge, 2013) and fine particle dust (Weingartner et al., 2003; Müller et al., 2011). However, the influence of BrC may be minimal in Alert as values of the AAE are between 0.5 and 1.5, suggesting predominantly fossil fuel influence (see Supplement and Fig. S1b). In addition, the Aethalometer response depends on filter loading and multiple scattering by the filter medium and sampled aerosol particles. Scattering correction thus becomes important in cases when the aerosol has higher scattering with respect to total extinction (absorption + scattering), i.e., absorption is low. This is not the case in Alert especially during the Arctic haze time. Summertime measurements could fall into this scenario. Recently, Backman et al. (2016) proposed a reduction of a factor of 3.2 in the light absorption coefficients derived from the Aethalometer due to multiple scattering enhancements associated with particles collected on the filter. These enhancements are considered, at least in part, in the EBC estimate by the $\alpha_{\text {ap }}$ value used with the Aethalometer, but there remains uncertainty in $\alpha_{\text {ap }}$, including the use of a constant value for all conditions. EBC (unmodified) needs to be evaluated due to these reasons in comparison to absolute measurement mass techniques.

\subsubsection{EC}

EC can be influenced by components that co-elute with oxygenated $\mathrm{OC}$ or $\mathrm{BrC}$ and may not be detected as $\mathrm{rBC}$ by the SP2 but measured by the thermal method as EC, including humic substances (natural organic material in soil and water) and humic-like substances (HULIS; e.g., Graber and Rudich, 2006) and dust. The techniques for measuring $\mathrm{rBC}$ and $\mathrm{EC}$ examine different parts of the atmospheric BC thermal spectrum (Andreae and Gelencsér, 2006): $\mathrm{rBC}$ is at the refractory end $\left(3600^{\circ} \mathrm{C}\right)$, whereas EC by this thermal method is the residual part of carbon mass after heating to $900^{\circ} \mathrm{C}$, and it will include $\mathrm{rBC}$ and possibly some non-BC carbonaceous components that would be interpreted as BC. As shown in Fig. 8, the weekly differences in EC and rBC (EC-rBC) exhibit a moderate association with the POC plus CC (POC $+\mathrm{CC}$ ) component of the carbonaceous aerosol. By thermal definition, $\mathrm{POC}+\mathrm{CC}$ is the carbonaceous component that elutes at $870^{\circ} \mathrm{C}$ in helium (see Fig. 4), which is proportional to the amount of oxygenated OC (Chan et al., 2010) or BrC, and EC might not be completely separated with temperature from the POC + CC component. The higher scatter in the winter (green symbols, $r^{2}=0.3$ ) and spring (red symbols, $r^{2}=0.4$ ) data (Fig. 8 ) could be because there are influences of POC from multiple sources during these seasons,

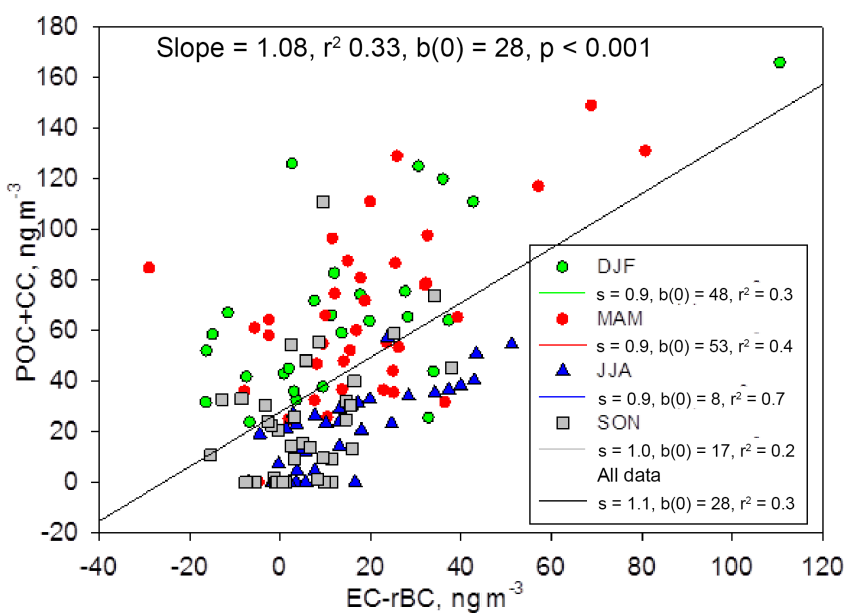

Figure 8. The weak but significant $(p<0.001)$ correlation among the difference between two weekly masses ( $\mathrm{EC}$ and $\mathrm{rBC}$ ) in Alert and the oxygenated carbon component, as represented by POC $+\mathrm{CC}$, shows some positive tendency, indicating incomplete separation of EC from other co-eluting thermal components. The correlation improves for summer (blue symbol, $r^{2}=0.7$ ), indicating a more consistent oxygenated source compared to other seasons where $r^{2}=0.3$.

whereas this correlation improves during summer (blue symbols, $r^{2}=0.7$ ), suggesting that the influences on POC and $\mathrm{EC} / \mathrm{rBC}$ are from a more consistent source. These strong associations among POC and EC-rBC suggest that during the temperature separation in the EC / OC thermogram, some of the POC component still remains in the EC fraction. These EC fractions, which are co-emitted with POC / BrC and likely formed from low temperature processes (relative to $3600^{\circ} \mathrm{C}$ ), may not be well detected as $\mathrm{rBC}$ by the SP2. This is why EC may overestimate $\mathrm{BC}$ relative to $\mathrm{rBC}$. There is a reason therefore that $\mathrm{EC}$ may overestimate $\mathrm{BC}$.

\subsection{3 rBC}

The rBC masses are derived under the assumptions that the calibration curve can be extrapolated linearly above $333 \mathrm{~nm}$ (including calibrations for no. 17, not shown in Fig. 2) and that the distributions of core diameters outside of the measured size region $(80-530 \mathrm{~nm})$ are represented by a lognormal function. The linear extrapolations of the calibration curves (e.g., Fig. 2) offer no suggestion of a bias. The distributions in Fig. 3 suggest that most of the rBC mass is accounted for within the above measured size range, and that the log-normal approximation is reasonable. The density estimate of the particles used in the calibration of the SP2 is a potential source of bias in the rBC estimate. The most up-todate and experimentally derived parameterization (Gysel et al., 2011) has been used here, but if the density assumption of the calibration particles differs from the "true" calibration particle density, the rBC mass concentrations will be biased. 
It cannot be also ruled out that Aquadag correction could also introduce some bias.

\subsubsection{BC mass best estimate}

In Alert, the absolute concentrations of $\mathrm{EBC}, \mathrm{EC}$, and $\mathrm{rBC}$ are each relatively small, but both EBC and EC are biased high relative to $\mathrm{rBC}$. As indicated above, there are valid reasons to expect those high biases. A clear bias in the rBC measurement cannot be identified, but neither can it be ruled out. The rBC mass concentrations will also be biased relative to true $\mathrm{BC}$ : $\mathrm{rBC}$ satisfies most of the five characteristics representing BC discussed by Petzold et al. (2013), but there may be some limitations as it pertains to the morphology criterion and the technique offers no guarantee that incandescing components are completely insoluble. Considering all arguments, including EC and rBC being more specific direct mass measurements than $\mathrm{EBC}$, which is a lightattenuation-inferred mass measurement, our best estimate of $\mathrm{BC}$ in Alert, to be used for comparison with chemical transport models, is an average of the $\mathrm{rBC}$ and $\mathrm{EC}$ measurements with a range bounded by the $\mathrm{rBC}$ and $\mathrm{EC}$ and their combined measurement uncertainties, respectively. Thus, the best estimates of winter-, spring-, summer-, and fall-averaged BC with atmospheric variability in Alert for this study period are $49 \pm 28,30 \pm 26,22 \pm 13$, and $29 \pm 9 \mathrm{ng} \mathrm{m}^{-3}$, respectively. EBC mass is not used in the determination of best-estimate mass of $\mathrm{BC}$ as it is an inferred mass derived from optical measurements and needs to be evaluated against more direct mass measurements techniques in Alert, presented in the later section.

\subsection{Seasonal variability of MAC}

The MAC is used to derive a mass concentration from a particle light absorption measurement. For BC in a freshly emitted aerosol, MAC has been estimated to be $7.5 \pm 1.2 \mathrm{~m}^{2} \mathrm{~g}^{-1}$ at a wavelength of $550 \mathrm{~nm}$ (Bond et al., 2013). The MAC value will vary in time and space depending upon source emissions and transformation during transport as the particles age (Chan et al., 2011; Bond et al., 2013). In general, MAC increases as more material coats the BC as discussed in Sect. 3.2.2. Other important components of the aerosol that absorb visible light tend to have much weaker absorption efficiencies at visible wavelengths: approximately $0.009 \mathrm{~m}^{2} \mathrm{~g}^{-1}$ at $550 \mathrm{~nm}$ for dust (Petzold et al., 2009) and approximately $1 \mathrm{~m}^{2} \mathrm{~g}^{-1}$ at $550 \mathrm{~nm}$ for BrC (Kirchstetter et al., 2004; Chakrabarty et al., 2010). As discussed earlier, the influence of $\mathrm{BrC}$ due to biomass burning is minimal in Alert during the Arctic haze time for the data collected during 2011-2013 (AAE $\mathrm{avg}_{\text {g }}$ for April $=0.75 \pm 0.12$ ). Thus, that effect of $\mathrm{BrC}$ will be minimal on the MAC. The uncertainty in the MAC value for $\mathrm{BC}$ is associated with both the absorption measurement and the $\mathrm{BC}$ mass concentration measurement.
The estimated MAC values are illustrated in Fig. 9, where $\sigma_{\text {ap }}$ values are plotted against our best estimate for the BC mass concentrations (i.e., the average of $\mathrm{EC}$ and $\mathrm{rBC}$ ) for the spring (MAM) and winter (DJF) periods. In each plot, the black points represent all available data. Those data are scrutinized in two ways. First, to help reduce uncertainty in the mass concentration estimate, observations are excluded from the analysis if the magnitude of the difference between $\mathrm{EC}$ and $\mathrm{rBC}$ relative to the mass concentration estimate is greater than $75 \%$. This is an arbitrary constraint, but using 50 or $100 \%$ offers relatively small changes. For example, in the spring case, the slope and intercept of the red circles are 0.0080 and 0.22 , respectively, for a constraint of $50 \%$ and 0.0071 and 0.21 , respectively, for a constraint of $100 \%$. The impact on the winter results is less due to the higher correlations. As is evident in Fig. 9, the overall effect of this constraint is to reduce the impact of lower $\sigma_{\text {ap }}$ and mass concentration points, which have greater relative uncertainty. Second, the $\sigma_{\text {ap }}$ values are constrained to be greater than or equal to $0.2 \mathrm{Mm}^{-1}$. This is done to help further reduce the relative uncertainty associated with low $\sigma_{\text {ap }}$ values. In each of the spring and winter cases, this constraint removes only one data point: other such points are removed by the first constraint.

The mass concentration estimate is for $\mathrm{BC}$, and if the measured absorption is due to $\mathrm{BC}$ only then a best fit should go through the origin. The intercept could be a result of incomplete corrections for artifacts in the $\sigma_{\text {ap }}$ from the PSAP, it may represent the mean of other absorbing species or a combination of those two. With the intercept subtracted from the scrutinized data, the final curve (black crosses) represents our best estimate for light absorption as a function of BC mass concentration. Scatter in the data may also be due to either incomplete artifact corrections or variations in other lightabsorbing components of the particles. The greater scatter in the spring data compared with winter may be consistent with an increased presence of $\mathrm{BrC}$ during spring, since organic matter in Alert is a factor of 2 higher in the spring than during winter (Leaitch et al., 2017). There are 10 data points for the summer period (JJA), but none of them fall within the above constraints, largely due to the low mass concentrations and values of $\sigma_{\text {ap. }}$. For the fall, there are a total of five data points, two of which are constrained as above and both of which yield a MAC value of 13.4 after subtraction of a positive intercept of $0.02 \mathrm{Mm}^{-1}$. Reasons for the two relatively high fall values of MAC are unknown, but the spring and winter data offer larger datasets and consistent average MAC values: $7.6 \pm 3.8 \mathrm{~m}^{2} \mathrm{~g}^{-1}$ for spring and $7.7 \pm 3.8 \mathrm{~m}^{2} \mathrm{~g}^{-1}$ for winter. These MAC values for spring and winter are reported in Table 2.

There are only five 1-week averages (during April 2012 and November 2013) with corresponding MAC values and $D_{\mathrm{p}} / D_{\mathrm{c}}$ values from the coating analysis. Those MAC estimates, based on the average of $\mathrm{rBC}$ and $\mathrm{EC}$ and following the above criteria, for $550 \mathrm{~nm}$ wavelength are plotted against 

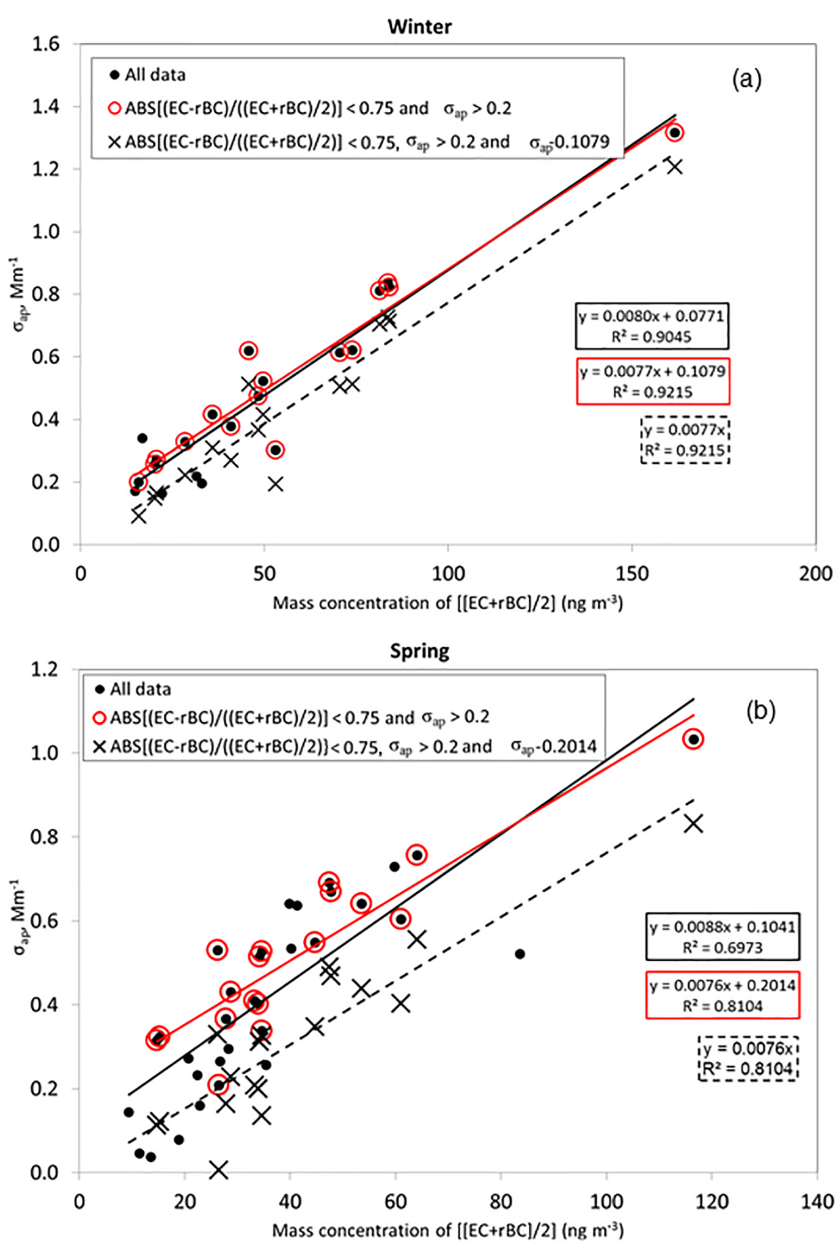

Figure 9. Light absorption coefficient $\left(\sigma_{\text {ap }}\right)$ at $550 \mathrm{~nm}$ versus the mass concentration of the average of $\mathrm{EC}$ and $\mathrm{rBC}$ for winter (a) and spring (b). Each plot shows all available data (black dots: 31 spring points and 21 winter points), a subset of all data scrutinized for closer agreement between $\mathrm{EC}$ and $\mathrm{rBC}$ and higher $\sigma_{\mathrm{ap}}$ (red circles: 18 spring points and 16 winter points) and the scrutinized subset with the intercept subtracted (black crosses). See text for discussion of the rationale.

weekly averaged $D_{\mathrm{p}} / D_{\mathrm{c}}$, as shown in Fig. 10 . Also shown in Fig. 10 is the variation in MAC for coating thickness expected from the core-shell model of Shiraiwa et al. (2010) starting with the MAC value for uncoated $\mathrm{BC}$ from Bond and Bergstrom (2006) of $7.5 \pm 1.2 \mathrm{~m}^{2} \mathrm{~g}^{-1}$. The present observations indicate a significant increase in MAC with increased coating thickness $\left(r^{2}=0.3, p<0.001\right)$, and the slope of the curve over the range of observations is steeper than the coreshell theoretical curve. The core-shell curve falls within the uncertainty of the regression curve at $880 \mathrm{~nm}$, where BC is the dominant absorber, and therefore these results cannot be interpreted as indicating stronger absorption than expected from the core-shell model. However, the core-shell model is an ideal representation, and enhancements of $50 \%$ or more in absorption are possible due to the presence of black car- bon aggregates as opposed to simple spherical cores (Bond et al., 2013). High RH has been found to amplify absorption by as much as a factor of 2.7 (Brem et al., 2012), but the RH in the sampling lines in Alert is $<40 \%$ and it is unlikely to be a significant influence here.

\subsection{Comparisons with other studies}

Ground-based measurements at other Arctic sites have also provided comparisons of various BC techniques. Eleftheriadis et al. (2009) found EBC and EC were comparable at Ny-Ålesund during July 1998 to August 1999. Raatikainen et al. (2015) showed comparisons among the SP2, the Aethalometer and the Multi-Angle Absorption Photometer (MAAP) measurements over a 2-month period (December 2011 to January 2012) in northern Finland. Their mean rBC estimate was $27 \mathrm{ng} \mathrm{m}^{-3}$ integrated over 75 to $655 \mathrm{~nm}$ sizes, compared with $38 \mathrm{ng} \mathrm{m}^{-3}$ integrated over 75 to $1000 \mathrm{~nm}$ for the same time period in Alert, and their average mean $\mathrm{rBC}$ diameter of $194 \mathrm{~nm}$ is the same as for Alert $(194 \pm 17 \mathrm{~nm})$. However, their regressions of $\mathrm{EBC}$ to $\mathrm{rBC}$ gave a slope of 4.3 compared with a slope of 1.6 for Alert. In Alert, located at $82.5^{\circ} \mathrm{N}$, the general circulation brings more direct transport from Siberia during this time period (Sharma et al., 2006), whereas the Finnish site, located at $67^{\circ} \mathrm{N}$, was influenced more by European sources. Massling et al. (2015) showed comparisons between EBC_aeth and EC at the Villium Research Station, Station Nord, Greenland $\left(81^{\circ} \mathrm{N}\right.$; ca. $700 \mathrm{~km}$ from Alert) for 2011-2013. A MAAP was used to measure EBC at $637 \mathrm{~nm}$ wavelength and a MAC value of $6.6 \mathrm{~m}^{2} \mathrm{~g}^{-1}$ (the default for the MAAP) was used to convert absorption from the MAAP to EBC mass concentrations. EC was determined using thermal analysis following the European Supersites for Atmospheric Aerosol Research (EUSAAR-2 protocol; Cavalli et al., 2010). The seasonal values of EBC are strikingly similar for Alert and Station Nord: respectively, 62 and $67 \mathrm{ng} \mathrm{m}^{-3}$ in winter; 57 and $54 \mathrm{ng} \mathrm{m}^{-3}$ in spring; 13 and $11 \mathrm{ng} \mathrm{m}^{-3}$ in summer; and 19 and $22 \mathrm{ng} \mathrm{m}^{-3}$ in fall. The European study reports $\mathrm{EBC}$ mass concentrations a factor of 2 higher than the EC mass concentrations.

Kondo et al. (2011) conducted a study in six cities in Asia by heating the sample to $300^{\circ} \mathrm{C}$ to burn off the organics (HULIS by $30 \%$ ) and lower the potential artificial enhancement in absorption by non-refractory compounds. They measured the absorption with a variant of the PSAP (COSMOS). They obtained MAC_rBC and MAC_EC values of 5.5 and $5.4 \mathrm{~m}^{2} \mathrm{~g}^{-1}$, respectively. The same comparison between PSAP and COSMOS absorption measurements showed $22 \%$ lower COSMOS absorption at Barrow, Alaska (Sinha et al., 2017). Although the two methods are different in concepts, the subtraction of the intercept in the plots in Fig. 9 reduces the PSAP value by an average of $50 \%$ for the spring and $25 \%$ for the winter. This gives a MAC of $7.6 \pm 3.8$ and $7.7 \pm 3.8$ for winter and spring which is similar to results 


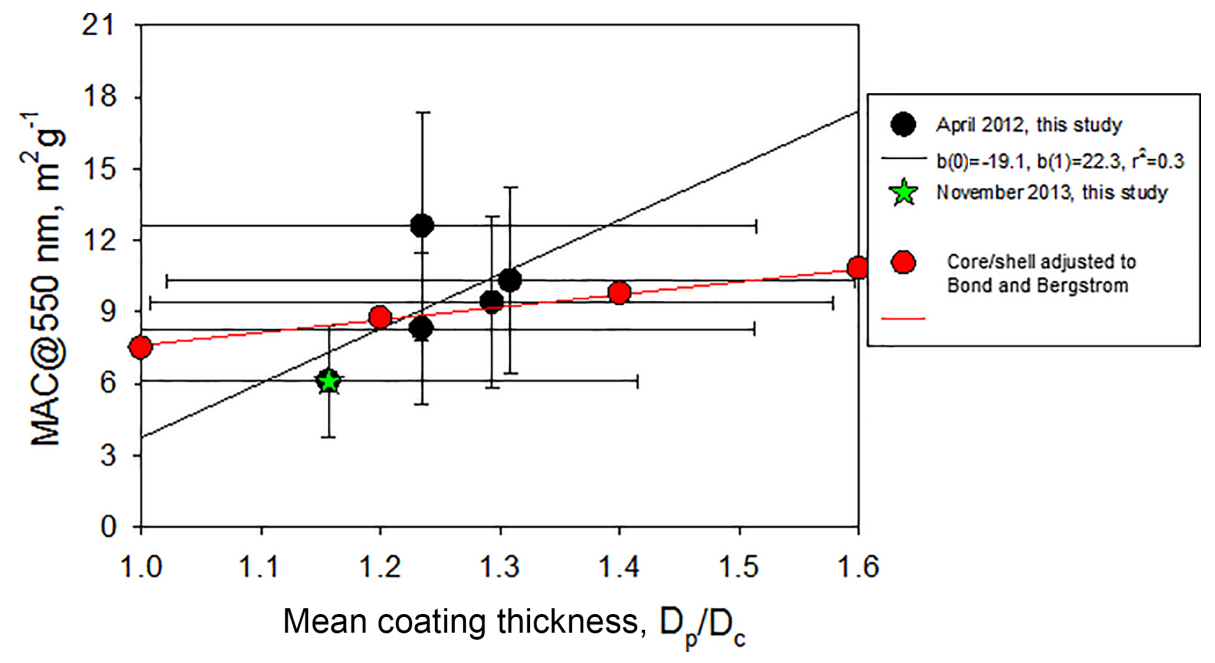

Figure 10. The comparison between the MAC and weekly averaged mean coating thickness shows a positive and significant relationship $(p<0.001)$. Aerosols seem to have thicker coatings in April (black circles) than in November (green star); also note that only values above the detection limits for MAC were considered. Red circles are adjusted core-shell to Bond and Bergstrom (2006) for uncoated particles at $7.5 \mathrm{~m}^{2} \mathrm{~g}^{-1}$.

of $9.0 \mathrm{~m}^{2} \mathrm{~g}^{-1}$ obtained by Sinha et al. (2017) at Barrow for the 2012 and 2013 time period.

The agreement improved between the weekly averages of uncorrected EBC from the Aethalometer and the best estimate of black carbon mass by using the best estimate of black carbon instead of $\mathrm{rBC}$ or EC masses alone in Alert (Fig. S2, red and green triangles; slope $=1, r^{2}=0.9$ and slope $=0.9$, $r^{2}=0.9$ for winter and spring and $r^{2}=0.9$ ) increasing confidence in the optically based mass measurements in Alert as trends have been drawn from these optical measurements (Sharma et al., 2013).

\section{Summary and conclusions}

Estimates of BC in Alert, Nunavut, over a 2-year and 9month period (March 2011 to December 2013) are made based on three different techniques: an Aethalometer for EBC, analysis of thermally evolved carbon from weekly quartz filters for EC, and an SP2 for rBC. Over the study period, on average results of pairwise analyses show both $\mathrm{EBC}$ and $\mathrm{EC}$ are 2.7 and 3 times higher than $\mathrm{rBC}$, respectively. $\mathrm{EBC}$ is biased higher than $\mathrm{EC}$ for the months of higher concentrations (November to May) and EC is biased higher than EBC during the lower-concentration summer months (June-August). The winter-spring EBC bias is attributed to the presence of absorbing substances other than $\mathrm{BC}$ and by scattering associated with particles accumulating on the filter that can enhance absorption by the $\mathrm{BC}$ relative to the atmosphere. Uncertainties also exist in the specific attenuation coefficient used to convert Aethalometer light attenuation to $\mathrm{EBC}$, but it is unclear if or how that may bias the EBC mass estimate.
$\mathrm{EC}$ and $\mathrm{rBC}$ differ in that $\mathrm{EC}$, as measured here, is the carbon that evolves to $\mathrm{CO}_{2}$ after heating at $900^{\circ} \mathrm{C}$ in an oxygenrich atmosphere, while $\mathrm{rBC}$ is based on the incandescent signal from particles heated to approximately $3600^{\circ} \mathrm{C}$. Those rather substantial differences and an observed association of the difference between EC and $\mathrm{rBC}$ with POC plus CC suggest the present $\mathrm{EC}$ is likely biased high by some pyrolyzed OC. The calibration procedure is a possible source of a bias in the $\mathrm{rBC}$ measurements, but the magnitude and direction of a possible bias are not clear. The definition of $\mathrm{rBC}$ is a potential bias as it relates to BC. Refractory BC satisfies most of the five characteristics representing $\mathrm{BC}$ given by Petzold et al. (2013), but there may be some limitations as it pertains to the morphology criterion and the technique offers no guarantee that incandescing components are completely insoluble. This argument also applies to EBC and EC.

Our present best estimate of $\mathrm{BC}$ in Alert, offered for possible use in model evaluation, is an average of the $\mathrm{rBC}$ and $\mathrm{EC}$ measurements with a range bounded by the combined $\mathrm{rBC}$ and EC measurement uncertainties. For this study period, the best-estimate averaged BC in Alert with atmospheric standard deviation for the winter, spring, summer, and fall are $49 \pm 28,30 \pm 26,22 \pm 13$, and $29 \pm 9 \mathrm{ng} \mathrm{m}^{-3}$, respectively. The propagated uncertainties in the averaged mass during spring and winter are $\pm 30 \%$ but this uncertainty increased during summer and fall to around $\pm 40 \%$.

During summer and fall, the number concentrations of particles with detectable $\mathrm{rBC}$ are 5-10 times lower than during winter-spring, and exhibit a slightly smaller mode diameter. For $\mathrm{rBC}$ cores in the $160-180 \mathrm{~nm}$ range, the average ratio of total particle diameter to $\mathrm{rBC}$ core diameter $\left(D_{\mathrm{p}} / D_{\mathrm{c}}\right)$ was measured for April 2012 and October-November 2013 and was found to range from 1.25 to 1.4. For particles scatter- 
ing light equivalent to $200-400 \mathrm{~nm}$ PSL spheres, the fraction containing $\mathrm{rBC}$ cores is estimated to be between 10 and $16 \%$, but smaller undetectable $\mathrm{rBC}$ cores $(<80 \mathrm{~nm})$ in some of the scattering particles cannot be excluded.

Light absorption measured with a PSAP was used with the $\mathrm{EC}$ and $\mathrm{rBC}$ averages to calculate the MAC value at $550 \mathrm{~nm}$ wavelength \pm uncertainty and the results were $8 \pm 4,8 \pm 4$, $5 \pm 2.5$, and $9 \pm 4.5 \mathrm{~m}^{2} \mathrm{~g}^{-1}$, for winter, spring, summer, and fall, respectively. These values were further refined by adjusting the absorption to only black carbon and this resulted in winter and spring MAC of $7.6 \pm 3.8$ and $7.7 \pm 3.8 \mathrm{~m}^{2} \mathrm{~g}^{-1}$. Only winter and spring estimates of MAC were possible due to the low number of usable data points available from the summer and fall periods.

Data availability. The aerosol light absorption, equivalent black carbon, elemental carbon and refractory black carbon data used in this paper can be found in the Supplement.

\section{The Supplement related to this article is available online at https://doi.org/10.5194/acp-17-15225-2017- supplement.}

Competing interests. The authors declare that they have no conflict of interest.

Acknowledgements. The authors would like to acknowledge the Department of National Defense and Environment and Climate Change Canada for operating the Dr. Neil Trivett Global Atmosphere Watch Observatory in Alert, NU. The authors would like to thank the operators and students for day-to-day instrument maintenance and activities at the Observatory. We are particularly grateful to Desiree Toom for providing assistance with the calibration systems and other aspects of the aerosol measurements and to our Arctic Coordinator, Andrew Platt, for his continuing support of our activities in Alert. Thanks are due to Vince Vetro for averaging of high-time-resolution $\mathrm{EBC}$ and $\mathrm{rBC}$ data to the EC filter times. Allan Bertram and Sarah Hanna from University of British Columbia were supported by the Natural Science and Engineering Research Council of Canada through a Climate Change and Atmospheric Research Grant (NETCARE).

Edited by: Willy Maenhaut

Reviewed by: Darrel Baumgardner and one anonymous referee

\section{References}

AMAP: AMAP Assessment 2015: Black carbon and ozone as Arctic climate forcers. Arctic Monitoring and Assessment Programme (AMAP), Oslo, Norway, vii + 116 pp., 2015.

Anderson, T. L. and Ogren, J. A.: Determining aerosol radiative properties using TSI 3563 integrating nephelometer, Aerosol Sci. Tech., 29, 57-69, 1998.
Andreae, M. O. and Gelencsér, A.: Black carbon or brown carbon? The nature of light-absorbing carbonaceous aerosols, Atmos. Chem. Phys., 6, 3131-3148, https://doi.org/10.5194/acp-63131-2006, 2006.

Backman, J., Schmeisser, L., Virkkula, A., Ogren, J. A., Asmi, E., Starkweather, S., Sharma, S., Eleftheriadis, K., Uttal, T., Jefferson, A., Bergin, M., and Makshtas, A.: On Aethalometer measurement uncertainties and multiple scattering enhancement in the Arctic, Atmos. Meas. Tech. Discuss., https://doi.org/10.5194/amt-2016-294, in review, 2016.

Barrie, L. A.: Arctic air pollution: an overview of current knowledge, Atmos. Environ., 20, 643-663, https://doi.org/10.1016/0004-6981(86)90180-0, 1986.

Baumgardner, D., Kok, G., and Raga, G: Warming of the Arctic lower stratosphere by light absorbing particles, Geophys. Res. Lett., 31, 10-13, https://doi.org/10.1029/2003GL018883, 2004.

Bohren, C. F. and Huffman, D. R.: Absorption and scattering of light by small particles, A Wiley-Interscience Publication, John Wiley \& Sons, Inc., New York, USA, 1983.

Bond, T. C. and Bergstrom, R. W.: Light absorption by carbonaceous particles: an investigative review, Aerosol Sci. Tech., 40, 27-67, 2006.

Bond, T. C., Anderson, T. L., and Campbell, D.: Calibration and intercomparison of filter-based measurements of visible light absorption by aerosols, Aerosol Sci. Tech., 30, 582-600, 1999.

Bond, T. C., Doherty, S. J., Fahey, D. W., Forster, P. M., Berntsen, T., DeAngelo, B. J., Flanner, M. G., Ghan, S., Kärcher, B., Koch, D., Kinne, S., Kondo, Y., Quinn, P. K., Sarofim, M. C., Schultz, M. G., Schulz, M., Venkataraman, C., Zhang, H., Zhang, S., Bellouin, N., Guttikunda, S. K., Hopke, P. K., Jacobson, M. Z., Kaiser, J. W., Klimont, Z., Lohmann, U., Schwarz, J. P., Shindell, D., Storelvmo, T., Warren, S. G., and Zender, C. S.: Bounding the role of black carbon in the climate system: a scientific assessment, J. Geophys. Res., 118, 5380-5552, https://doi.org/10.1002/jgrd.50171, 2013.

Brem, B. T., Gonzalez, F. C. M., Meyers, S. R., Bond, T. C., and Rood, M. J.: Laboratory- measured optical properties of inorganic and organic aerosols at relative humidities up to 95\%, Aerosol Sci. Tech., 46, 178-190, https://doi.org/10.1080/02786826.2011.617794, 2012.

Brock, C. A., Cozic, J., Bahreini, R., Froyd, K. D., Middlebrook, A. M., McComiskey, A., Brioude, J., Cooper, O. R., Stohl, A., Aikin, K. C., de Gouw, J. A., Fahey, D. W., Ferrare, R. A., Gao, R.-S., Gore, W., Holloway, J. S., Hübler, G., Jefferson, A., Lack, D. A., Lance, S., Moore, R. H., Murphy, D. M., Nenes, A., Novelli, P. C., Nowak, J. B., Ogren, J. A., Peischl, J., Pierce, R. B., Pilewskie, P., Quinn, P. K., Ryerson, T. B., Schmidt, K. S., Schwarz, J. P., Sodemann, H., Spackman, J. R., Stark, H., Thomson, D. S., Thornberry, T., Veres, P., Watts, L. A., Warneke, C., and Wollny, A. G.: Characteristics, sources, and transport of aerosols measured in spring 2008 during the aerosol, radiation, and cloud processes affecting Arctic Climate (ARCPAC) Project, Atmos. Chem. Phys., 11, 24232453, https://doi.org/10.5194/acp-11-2423-2011, 2011.

Cavalli, F., Viana, M., Yttri, K. E., Genberg, J., and Putaud, J.-P.: Toward a standardised thermal-optical protocol for measuring atmospheric organic and elemental carbon: the EUSAAR protocol, Atmos. Meas. Tech., 3, 79-89, https://doi.org/10.5194/amt-3-79$2010,2010$. 
Chakrabarty, R. K., Moosmüller, H., Chen, L.-W. A., Lewis, K., Arnott, W. P., Mazzoleni, C., Dubey, M. K., Wold, C. E., Hao, W. M., and Kreidenweis, S. M.: Brown carbon in tar balls from smoldering biomass combustion, Atmos. Chem. Phys., 10, 63636370, https://doi.org/10.5194/acp-10-6363-2010, 2010.

Chan, T. W., Huang, L., Leaitch, W. R., Sharma, S., Brook, J. R., Slowik, J. G., Abbatt, J. P. D., Brickell, P. C., Liggio, J., Li, S.M., and Moosmüller, H.: Observations of OM / OC and specific attenuation coefficients (SAC) in ambient fine PM at a rural site in central Ontario, Canada, Atmos. Chem. Phys., 10, 2393-2411, https://doi.org/10.5194/acp-10-2393-2010, 2010.

Chan, T. W., Brook, J. R., Smallwood, G. J., and Lu, G.: Time-resolved measurements of black carbon light absorption enhancement in urban and near-urban locations of southern Ontario, Canada, Atmos. Chem. Phys., 11, 10407-10432, https://doi.org/10.5194/acp-11-10407-2011, 2011.

Chow, J. C., Watson, J. G., Crow, D., Lowenthal, D. H., and Merrifield, T.: Comparison of IMPROVE and NIOSH carbon measurements, Aerosol Sci. Tech., 34, 23-34, 2001.

Clarke, A. D. and Noone, K. J.: Soot in the Arctic snowpack: a cause for perturbations in radiative transfer, Atmos. Environ., 19, 2045-2053, 1985.

Croft, B., Wentworth, G. R., Martin, R. V., Leaitch, W. R., Murphy, J. G., Murphy, B. N., Kodros, J. K., Abbatt, J. P. D., and Pierce, J. R.: Contribution of Arctic seabird-colony ammonia to atmospheric particles and cloud-albedo radiative effect, Nat. Commun., 7, 13444, https://doi.org/10.1038/ncomms13444, 2016.

Cross, E. S., Onasch, T. B., Ahern, A., Wrobel, W., Slowik, J. G., Olfert, J., Lack, D. A., Massoli, P., Cappa, C. D., Schwarz, J. P., Spackman, J. R., Fahey, D. W., Sedlacek, A., Trimborn, A., Jayne, J. T., Freedman, A., Williams, L. R., Ng, N. L., Mazzoleni, C., Dubey, M., Brem, B., Kok, G., Subramanian, R., Freitag, S., Clarke, A., Thornhill, D., Marr, L. C., Kolb, C. E., Worsnop, D. R., and Davidovits, P.: Soot particle studies- instrument intercomparison-project overview, Aerosol Sci. Tech., 44, 592-611, 2010.

Dahlkötter, F., Gysel, M., Sauer, D., Minikin, A., Baumann, R., Seifert, P., Ansmann, A., Fromm, M., Voigt, C., and Weinzierl, B.: The Pagami Creek smoke plume after long-range transport to the upper troposphere over Europe - aerosol properties and black carbon mixing state, Atmos. Chem. Phys., 14, 6111-6137, https://doi.org/10.5194/acp-14-6111-2014, 2014.

Dumont, M., Brun, E., Picard, G., Michou, M., Libois, Q., Petit, J.-R., Geyer, M., Morin, S., and Josse, B.: Contribution of lightabsorbing impurities in snow to Greenland's darkening since 2009, Nat. Geosci., 7, 509-512, 2014.

Eleftheriadis, K., Vratolis, S., and Nyeki, S.: Aerosol black carbon in the European Arctic: measurements at Zeppelin station, Ny-Ålesund, Svalbard from 1998-2007, Geophys. Res. Lett., 36, L02809, https://doi.org/10.1029/2008GL035741, 2009.

Gao, R. S., Schwarz, J. P., Kelly, K. K., Fahey, D. W., Watts, L. A., Thompson, T. L., Spackman, J. R., Slowik, J. G., Cross, E. S., Han, J.-H., Davidovits, P., Onasch, T. B., and Worsnop, D. R.: A novel method for estimating lightscattering properties of soot aerosols using a modified single particle soot photometer, Aerosol Sci. Tech., 41, 125-135, https://doi.org/10.1080/02786820601118398, 2007.

Garrett, T. J., Brattström, S., Sharma, S., Worthy, D. E. J., and Novelli, P.: The role of scavenging in the seasonal transport of black carbon and sulfate to the Arctic, Geophys. Res. Lett., 38, L16805, https://doi.org/10.1029/2011GL048221, 2011.

Gong, S. L., Zhao, T. L., Sharma, S., Toom-Sauntry, D., Lavoué, D., Zhang, X. B., Leaitch, W. R., and Barrie, L. A.: Identification of trends and interannual variability of sulfate and black carbon in the Canadian high Arctic: 1981-2007, J. Geophys. Res., 115, D07305, https://doi.org/10.1029/2009JD012943, 2010.

Graber, E. R. and Rudich, Y.: Atmospheric HULIS: How humiclike are they? A comprehensive and critical review, Atmos. Chem. Phys., 6, 729-753, https://doi.org/10.5194/acp-6-7292006, 2006.

Gysel, M., Laborde, M., Olfert, J. S., Subramanian, R., and Gröhn, A. J.: Effective density of Aquadag and fullerene soot black carbon reference materials used for SP2 calibration, Atmos. Meas. Tech., 4, 2851-2858, https://doi.org/10.5194/amt-4-2851-2011, 2011.

Hansen, J., Lacis, A., Rind, D., Russell, G., Stone, P., Fung. I., Ruedy, R., and Lerner, J.: Climate sensitivity: analysis of feedback mechanisms, in Climate Processes and Climate Sensitivity, Geophys. Monogr., 29, edited by: Hansen, J. E. and Takahashi, T., 130-163, Washington, D.C., USA, 1984.

Hegg, D. A., Warren, S. G., Grenfell, T. C., Doherty, S. J., Larson, T. V., and Clarke, A. D.: Source attribution of black carbon in Arctic snow, Environ. Sci. Technol., 43, 4016-4021, 2009.

Hirdman, D., Sodemann, H., Eckhardt, S., Burkhart, J. F., Jefferson, A., Mefford, T., Quinn, P. K., Sharma, S., Ström, J., and Stohl, A.: Source identification of short-lived air pollutants in the Arctic using statistical analysis of measurement data and particle dispersion model output, Atmos. Chem. Phys., 10, 669-693, https://doi.org/10.5194/acp-10-669-2010, 2010.

Hoffer, A., Gelencsér, A., Guyon, P., Kiss, G., Schmid, O., Frank, G. P., Artaxo, P., and Andreae, M. O.: Optical properties of humiclike substances (HULIS) in biomass-burning aerosols, Atmos. Chem. Phys., 6, 3563-3570, https://doi.org/10.5194/acp-6-35632006, 2006.

Hopper, J. F., Worthy, D. E. J., Barrie, L. A., and Trivett, N. B. A.: Atmospheric observations of aerosol black carbon, carbon dioxide, and methane in the high Arctic, Atmos. Environ., 28, 3047-3054, 1994

Huang, L., Brook, J. R., Zhang, W., Li, S.-M., Graham, L., Ernst, D., Chivulescu, A., and Lu, G.: Stable isotope measurements of carbon fractions (OC / EC) in airborne particulate: a new dimension for source characterization and apportionment, Atmos. Environ., 40, 2690-2705, 2006.

Huang, L., Zhang, W., Sharma, S., Brook, J., Leaitch, R., Czimczik, C., Santos, G. M., He, K., Duan, F., and Yang, F.: Aerosol carbon isotopes at Alert, Canada: understanding emission sources of black carbon transported to the Arctic, Goldschmidt2015 Abstracts, Geochemical society and European Association of Geochemistry, 1336, Cambridge publications, UK, 2015.

Isaac, G. A., Leaitch, W. R., Strapp J. W., and Anlauf, K. G.: Summer aerosol profiles over Algonquin Park, Atmos. Environ., 20, 157-172, 1986.

Iziomon, M. G., Lohmann, U., and Quinn, P. K.: Summertime pollution events in the Arctic and potential implications, J. Geophys. Res., 111, D12206, https://doi.org/10.1029/2005JD006223, 2006.

Karanasiou, A., Minguillón, M. C., Viana, M., Alastuey, A., Putaud, J.-P., Maenhaut, W., Panteliadis, P., Mocnik, G., Favez, O., and 
Kuhlbusch, T. A. J.: Thermal-optical analysis for the measurement of elemental carbon (EC) and organic carbon (OC) in ambient air a literature review, Atmos. Meas. Tech. Discuss., https://doi.org/10.5194/amtd-8-9649-2015, 2015.

Keegan, K. M., Albert, M. R., McConnell, J. R., and Baker, I.: Climate change and forest fires synergistically drive widespread melt events of the Greenland ice sheet, P. Natl. Acad. Sci. USA, 111, 7964-7967, 2014.

Kirchstetter, T. W., Novakov, T., and Hobbs, P. V.: Evidence that the spectral dependence of light absorption by aerosols is affected by organic carbon, J. Geophys. Res., 109, D21208, https://doi.org/10.1029/2004JD004999, 2004.

Kondo, Y., Sahu, L., Moteki, N., Khan, F., Takegawa, N., Liu, X., Koike, M., and Miyakawa, T.: Consistency and traceability of black carbon measurements made by laser-induced incandescence, thermal-optical transmittance, and filter-based photo-absorption techniques, Aerosol Sci. Tech., 45, 295-312, https://doi.org/10.1080/02786826.2010.533215, 2011.

Laborde, M., Mertes, P., Zieger, P., Dommen, J., Baltensperger, U., and Gysel, M.: Sensitivity of the Single Particle Soot Photometer to different black carbon types, Atmos. Meas. Tech., 5, 10311043, https://doi.org/10.5194/amt-5-1031-2012, 2012.

Lack, D. A. and Langridge, J. M.: On the attribution of black and brown carbon light absorption using the Ångström exponent, Atmos. Chem. Phys., 13, 10535-10543, https://doi.org/10.5194/acp-13-10535-2013, 2013.

Lack, D. A., Bahreini, R., Langridge, J. M., Gilman, J. B., and Middlebrook, A. M.: Brown carbon absorption linked to organic mass tracers in biomass burning particles, Atmos. Chem. Phys., 13, 2415-2422, https://doi.org/10.5194/acp-132415-2013, 2013.

Leaitch, W. R., Russell, L. M., Liu, J., Kolonjari, F., Toom, D., Huang, L., Sharma, S., Chivulescu, A., Veber, D., and Zhang, W.: Organic Functional Groups in the Submicron Aerosol at 82.5 ${ }^{\circ} \mathrm{N}$ from 2012 to 2014, Atmos. Chem. Phys. Discuss., https://doi.org/10.5194/acp-2017-511, in review, 2017.

Liousse, C., Cachier, H., and Jennings, S. G.: Optical and thermal measurements of black carbon aerosol content in different environments: variation of the specific attenuation cross-section, sigma $(\sigma)$, Atmos. Environ., 27, 1203-1211, 1993.

Massling, A., Nielsen, I. E., Kristensen, D., Christensen, J. H., Sørensen, L. L., Jensen, B., Nguyen, Q. T., Nøjgaard, J. K., Glasius, M., and Skov, H.: Atmospheric black carbon and sulfate concentrations in Northeast Greenland, Atmos. Chem. Phys., 15, 9681-9692, https://doi.org/10.5194/acp-15-9681-2015, 2015.

McConnell, J. R., Edwards, E., Kok, G. L., Flanner, M. G., Zender, C. S., Saltzman, E. S., Banta, J. R., Pasteris, D. R., Carter, M. M., and Kahl, J. D.: 20th-century industrial black carbon emissions altered Arctic climate, Science, 317, 1381-1384, 2007.

Metcalf, A. R., Craven, J. S., Ensberg, J. J., Brioude, J., Angevine, W., Sorooshian, A., Duong, H. T., Jonsson, H. H., Flagan, R. C., and Seinfeld, J. H.: Black carbon aerosol over the Los Angeles Basin during CalNex, J. Geophys. Res., 117, D00V13, https://doi.org/10.1029/2011jd017255, 2012.

Moffet, R. C., O’Brien, R. E., Alpert, P. A., Kelly, S. T., Pham, D. Q., Gilles, M. K., Knopf, D. A., and Laskin, A.: Morphology and mixing of black carbon particles collected in central California during the CARES field study, Atmos. Chem. Phys., 16, 1451514525, https://doi.org/10.5194/acp-16-14515-2016, 2016.
Moteki, N. and Kondo, Y.: Dependence of laser-induced incandescence on physical properties of black carbon aerosols: measurements and theoretical interpretation, Aerosol Sci. Tech., 44, 663675, https://doi.org/10.1080/02786826.2010.484450, 2010.

Moteki, N., Kondo, Y., and Nakamura, S.: Method to measure refractive indices of small nonspherical particles: application to black carbon particles, J. Aerosol Sci., 41, 513-521, https://doi.org/10.1016/j.jaerosci.2010.02.013, 2010.

Müller, T., Henzing, J. S., de Leeuw, G., et al.: Characterization and intercomparison of aerosol absorption photometers: result of two intercomparison workshops, Atmos. Meas. Tech., 4, 245268, https://doi.org/10.5194/amt-4-245-2011, 2011.

NIOSH: Elemental carbon (Diesel Exhaust), in: NIOSH Manual of Analytical Methods. National Institute of Occupational Safety and Health, Cincinnati, OH, USA, 1996.

NIOSH: Method 5040 Issue 3 (Interim): elemental carbon (Diesel Exhaust), in: NIOSH Manual of Analytical Methods. National Institute of Occupational Safety and Health, Cincinnati, OH, USA, 1999.

Ogren, J. A.: Comment on "Calibration and intercomparison of filter-based measurements of visible light absorption by aerosols", Aerosol Sci. Tech., 44, 589-591, 1608 https://doi.org/10.1080/02786826.2010.482111, 2010.

Petzold, A., Rasp, K., Weinzierl, B., Esselborn, M., Hamburger, T., Dörnbrack, A., Kandler, K., Schutz, L., Knippertz, P., Fiebig, M., and Virkkula, A.: Saharan dust absorption and refractive index and from aircraft-based observations during SAMUM 2006, Tellus B, 61, 118-130, 2009.

Petzold, A., Veira, A., Mund, S., Esselborn, M., Kiemle, C., Weinzierl, B., Hamburger, T., Ehret, G., Lieke, K., and Kandler, K.: Mixing of mineral dust with urban pollution aerosol over Dakar (Senegal): impact on dust physicochemical and radiative properties, Tellus B, 63, 619-634, https://doi.org/10.1111/j.1600-0889.2011.00547.x, 2011.

Petzold, A., Ogren, J. A., Fiebig, M., Laj, P., Li, S.-M., Baltensperger, U., Holzer-Popp, T., Kinne, S., Pappalardo, G., Sugimoto, N., Wehrli, C., Wiedensohler, A., and Zhang, X.-Y.: Recommendations for reporting "black carbon" measurements, Atmos. Chem. Phys., 13, 8365-8379, https://doi.org/10.5194/acp13-8365-2013, 2013.

Qi, L., Li, Q., Henze, D. K., Tseng, H.-L., and He, C.: Sources of springtime surface black carbon in the Arctic: an adjoint analysis for April 2008, Atmos. Chem. Phys., 17, 9697-9716, https://doi.org/10.5194/acp-17-9697-2017, 2017.

Quinn, P. K., Shaw, G., Andrews, E., Dutton, E. G., Ruoho-Airola, T., and Gong, S. L.: Arctic haze: current trends and knowledge gaps, Tellus B, 59, 99-114, 2007.

Raatikainen, T., Brus, D., Hyvärinen, A.-P., Svensson, J., Asmi, E., and Lihavainen, H.: Black carbon concentrations and mixing state in the Finnish Arctic, Atmos. Chem. Phys., 15, 1005710070, https://doi.org/10.5194/acp-15-10057-2015, 2015.

Sahu, L. K., Kondo, Y., Moteki, N., Takegawa, N., Zhao, Y., Cubison, M. J., Jimenez, J. L., Vay, S., Diskin, G. S., Wisthaler, A., Mikoviny, T., Huey, L. G., Weinheimer, A. J., and Knapp, D. J.: Emission characteristics of black carbon in anthropogenic and biomass burning plumes over California during ARCTAS-CARB 2008, J. Geophys. Res., 117, D16302, https://doi.org/10.1029/2011JD017401, 2012. 
Sand, M., Berntsen, T. K., Kay, J. E., Lamarque, J. F., Seland, Ø., and Kirkevåg, A.: The Arctic response to remote and local forcing of black carbon, Atmos. Chem. Phys., 13, 211-224, https://doi.org/10.5194/acp-13-211-2013, 2013.

Sand, M., Berntsen, T. K., von Salzen, K., Flanner, M. G., Langner, J., and Victor, D. G: Response of the Arctic temperature to changes in emissions of short-lived climate forcers, Nat. Clim. Chang., 6, 286-289, https://doi.org/10.1038/nclimate2880, 2016.

Schwarz, J. P., Gao, R. S., Fahey, D. W., Thomson, D. S., Watts, L. A., Wilson, J. C., Reeves, J. M., Darbeheshti, M., Baumgardner, D. G., Kok, G. L., Chung, S. H., Schulz, M., Hendricks, J., Lauer, A., Karcher, B., Slowik, J. G., Rosenlof, K. H., Thompson, T. L., Langford, A. O., Loewenstein, M., and Aikin, K. C.: Single-particle measurements of mid-latitude black carbon and light-scattering aerosols from the boundary layer to the lower stratosphere, J. Geophys. Res., 111, D16207, https://doi.org/10.1029/2006jd007076, 2006.

Schwarz, J. P., Gao, R. S., Spackman, J. R., Watts, L. A., Thomson, D. S., Fahey, D. W., Ryerson, T. B., Peischl, J., Holloway, J. S., Trainer, M., Frost, G. J., Baynard, T., Lack, D. A., De Gouw, J. A., Warneke, C., and Del Negro, L. A.: Measurement of the mixing state, mass, and optical size of individual black carbon particles in urban and biomass burning emissions, Geophys. Res. Lett., 35, L13810, https://doi.org/10.1029/2008GL033968, 2008.

Schwarz, J. P., Spackman, J. R., Gao, R. S., Watts, L. A., Stier, P., Schulz, M., Davis, S. M., Wofsy, S. C., and Fahey, D. W.: Global-scale black carbon profiles observed in the remote atmosphere and compared to models, Geophys. Res. Lett., 37, L18812, https://doi.org/10.1029/2010GL044372, 2010.

Sharma, S., Brook, J. R., Cachier, H., Chow, J., Gaudenzi, A., and Lu, G.: Light absorption and thermal measurements of black carbon in different regions of Canada, J. Geophys. Res., 107, D244771, https://doi.org/10.1029/2002JD002496, 2002.

Sharma, S., Lavoue, D., Cachier, H., Barrie, L. A., and Gong, S. L.: Long-term trends of the black carbon concentrations in the Canadian Arctic, J. Geophys. Res., 109, D15203, https://doi.org/10.1029/2003JD004331, 2004.

Sharma, S., Andrews, E., Barrie, L. A., Ogren, J. A., and Lavoué, D.: Variations and sources of the equivalent black carbon in the high Arctic revealed by long-term observations at Alert and Barrow: 1989-2003, J. Geophys. Res., 111, D14208, https://doi.org/10.1029/2005JD006581, 2006.

Sharma, S., Ishizawa, M., Chan, D., Lavoue, D., Andrews, E., Eleftheriadis, K., and Maksyutov, S.: 16-year simulation of Arctic black carbon: transport, source contribution, and sensitivity analysis on deposition, J. Geophys. Res., 118, 943-964, https://doi.org/10.1029/2012JD017774, 2013.
Sherman, J. P., Sheridan, P. J., Ogren, J. A., Andrews, E., Hageman, D., Schmeisser, L., Jefferson, A., and Sharma, S.: A multi-year study of lower tropospheric aerosol variability and systematic relationships from four North American regions, Atmos. Chem. Phys., 15, 12487-12517, https://doi.org/10.5194/acp-15-124872015, 2015.

Shiraiwa, M., Kondo, Y., Iwamoto, T., and Kita, K.: Amplification of light absorption of black carbon by organic coating, Aerosol Sci. Tech., 44, 46-54, https://doi.org/10.1080/02786820903357686, 2010.

Sinha, P. R., Kondo, Y., Koike, M., Ogren, J. A., Jefferson, A., Barrett, T. E., Sheesley, R. J., Ohata, S., Monteki, N., Coe, H., Liu, D., Irwin, M., Tunved, P., Quinn, P. K., and Zhao, Y.: Evaluation of ground-based black carbon measurements by filter-based photometers at two Arctic sites, J. Geophys. Res.-Atmos., 122, 3544-3572, https://doi.org/10.1002/2016JD025843, 2017.

Stephens, M., Turner, N., and Sandberg, J.: Particle identification by laser-induced incandescence in a solid-state laser cavity, Appl. Optics, 42, 3726-3736, 2003.

Stone, R. S., Sharma, S., Herber, A., Eleftheriadis, K., and Nelson, D. W.: A characterization of Arctic aerosols on the basis of aerosol optical depth and black carbon measurements, Elementa: Science of the Anthropocene, 2, 000027, https://doi.org/10.12952/journal.elementa.000027, 2015.

Taylor, J. W., Allan, J. D., Liu, D., Flynn, M., Weber, R., Zhang, X., Lefer, B. L., Grossberg, N., Flynn, J., and Coe, H.: Assessment of the sensitivity of core / shell parameters derived using the singleparticle soot photometer to density and refractive index, Atmos. Meas. Tech., 8, 1701-1718, https://doi.org/10.5194/amt-8-17012015, 2015.

UNEP/WMO: Integrated assessment of black carbon and tropospheric ozone, UNEP and WMO, Geneva, Switzerland, 285 pp., 2011.

Weingartner, E., Saathoff, H., Schnaiter, M., Streit, N., Bitnar, B., and Baltensperger, U.: Absorption of light by soot particles: determination of the absorption coefficient by means of aethalometers, J. Aerosol Sci., 34, 1445-1463, 2003.

WMO/GAW: Aerosol measurement procedures, guidelines and recommendations, 2nd Edition, 103, WMO-No. 1177, August 2016 , available at: http://library.wmo.int/opac/index.php?lvl=notice_ display\&id=19622 (last access: 15 December 2017), 2016.

Xu, J.-W., Martin, R. V., Morrow, A., Sharma, S., Huang, L., Leaitch, W. R., Burkart, J., Schulz, H., Zanatta, M., Willis, M. D., Henze, D. K., Lee, C. J., Herber, A. B., and Abbatt, J. P. D.: Source attribution of Arctic black carbon constrained by aircraft and surface measurements, Atmos. Chem. Phys., 17, 1197111989, https://doi.org/10.5194/acp-17-11971-2017, 2017. 